\title{
Grenada: Interim Poverty Reduction Strategy Paper
}

Poverty Reduction Strategy Papers (PRSPs) are prepared by member countries in broad consultation with stakeholders and development partners, including the staffs of the World Bank and the IMF. Updated every three years with annual progress reports, they describe the country's macroeconomic, structural, and social policies in support of growth and poverty reduction, as well as associated external financing needs and major sources of financing. This country document for Grenada, dated March 27, 2006, is being made available on the IMF Website by agreement with the member country as a service to users of the IMF website.

To assist the IMF in evaluating the publication policy, reader comments are invited and may be sent by e-mail to publicationpolicy@imf.org.

Copies of this report are available to the public from

International Monetary Fund • Publication Services

$70019^{\text {th }}$ Street, N.W. • Washington, D.C. 20431

Telephone: (202) 623-7430 • Telefax: (202) 623-7201

E-mail: publications@imf.org•Internet: http://www.imf.org

Price: $\$ 15.00$ a copy

\section{International Monetary Fund \\ Washington, D.C.}





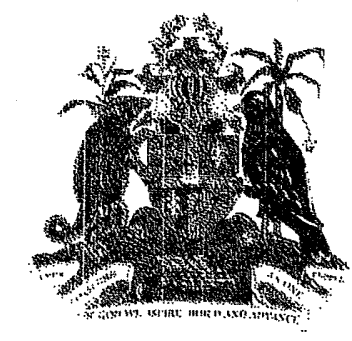

MINISTRY OF FINANCE,

FINANCIAL COMPLEX,

THE CARENAGE,

ST. C.EORGE'S,

GFINADA, W.I.

March 27, 2006

Mr. Rodrigo de Rato,

Managing Director,

International Monetary Fund

$70019^{\text {th }}$ Strest, NW,

Washington, DC 20431

USA

Dear Mr. de Rato

The attached document entitled Grenada: Poverty Eradication Strategy, outlines the Government of Grenada's social development Agenda. Drawing on this document we are in the process of preparing a comprehensive poverty reduction strategy, which we expect to finalize in the coming months. This document has benefited from extensve public consultation, and authorize the IMF to arrange for it to be posted on the Fund's website.

Sincerely

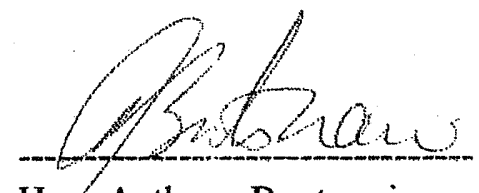

Hor. Anthony Boatswain

MINISTER FOR FINANCE AND PLANNING 


\subsection{INTRODUCTION}

\subsection{Background}

The Government of Grenada ranks poverty eradication as a premier policy objective to be achieved through the promotion of sustained and robust growth in the economy and the creation of employment, production and income generating activities especially in the rural communities.

In 1999, the Government of Grenada elaborated a Poverty Assessment Survey which revealed significant gaps and shortcomings in the social sector of the Grenadian economy. The Survey identified the need for a concerted effort by the authorities to address the deteriorating state of the social environment and to formulate a clear, consistent and integrated social policy framework and national plan for social development and poverty eradication.

The expressed medium term goal as expressed in 2000-2002 Medium Term Economic Strategy Paper (MTESP) is to "reposition the Grenadian economy as a more diversified, competitive and knowledge based economy, thereby ensuring the quality of life of all its citizens is permanently enhanced" (MTESP, 2000).

The Government of Grenada in cooperation with civil society and in collaboration with regional and international organizations, in particular the OECS, UNDP and CDB, developed and executed a detailed programme of activities geared to inform a National Social Development Policy and Poverty Strategy and Plan.

The Poverty Eradication Strategy was completed after wide ranging consultations on the local level. The strategy reiterates government's commitments to the eradication of poverty and highlights the importance of engendering meaningful involvement of all stakeholders in order to achieve economic growth and development and improvements in the social infrastructure.

Subsequent to the completion of the Poverty Eradication Strategy and Plan, Grenada suffered the devastating effects of two major hurricanes and an unprecedented rise in prices due to oil price adjustments.

On September $7^{\text {th }} 2004$, hurricane Ivan unleashed its wrath on Grenada and left a trail of damage in its path. A damage assessment report conducted by the Organization of Eastern Caribbean States indicated that the damage amounted to over 200 percent of the Country's gross domestic product. The assessment was done in four basic categories namely; social, productive, infrastructure, and environment, and the direct and indirect damages were computed. The extent of the damage translated into serious consequences for the poverty situation in the country. The overall computation of the damage included a detailed macroeconomic assessment of the economy prior to the disaster, the projected macroeconomic performance without the disaster, and the estimated economic performance 
of the economy as a result of both direct and indirect costs and effects associated with Hurricane Ivan. The damage assessment report specifically recommended a rehabilitation and reconstruction strategy and programme, the need to reduce vulnerability over time and increase resilience to natural disasters and the need for reconstruction efforts to be married with strategic policy interventions. The Government of Grenada heeded the advice of the experts and elaborated a detailed reconstruction and development programme.

On July 14, 2005 in the midst of the reconstruction and development programme, the country was again hit by a major hurricane. According to a report done by the Organization of Eastern Caribbean States, the direct and indirect damage caused by Hurricane Emily was estimated at 12.9 percent of the gross domestic product. Like the previous report, the damage assessment was conducted for the four major sectors and included pre and post disaster economic situation analysis. The report then reiterated the conclusions with respect to strategic directioning of the economy which were detailed in the earlier assessment.

The Grenadian economy received the third in a series of significant economy shocks with the significant increases in the prices of imported fuel and related products. The Ministry of Finance estimated that the immediate inflationary effect of the oil price adjustment will be a 6 percent increase in the prices of goods and services.

Based on the foregoing, the Government of Grenada is committed to the elaboration of a full-fledged Poverty Reduction Strategy and Action Plan within the next 12 months. The Strategy and Action Plan will be informed by another detailed Poverty Assessment Report and an extensive programme of public consultations throughout the country.

This document therefore is prepared as an interim Poverty Reduction Strategy Paper (IPRSP) to guide the programme for poverty reduction in the interim period. The I-PRSP is based on the draft Poverty Eradication Strategy and other policy documentation elaborated since the completion of the draft strategy.

\subsection{Government's Commitment to Poverty Eradication}

Clear policy statements on Government's commitment to poverty eradication were made at several fora including the year 2000 Millennium Declaration and the subsequent national budgeting processes. In fact, the theme of the year 2000 budget read as follows "Poverty Eradication Through Growth, Equity and Peoples' Participation in the New Millennium". This theme was followed by an objective statement which read "To Establish a Platform for the Longer Term Eradication of Poverty". In 2001 and 2002 the Government continued on the poverty theme and focused the 2001 and 2002 budgets as follows "Towards a Knowledge-based Economy with Equity" and "Stimulating Economic Growth, Increasing Food Security and National Productivity". In 2003, the theme was "Stimulating Economic Growth, Promoting Private Investments and Human Development" and in year 2004 the theme was "Promoting Economic and Social Development Through Peoples' Participation". The theme for budget 2006 is "Reaching Consensus on Promoting Growth, Macroeconomic Stability and Poverty Alleviation Measure." In sum, the statements clearly 
indicate the Government's policy towards poverty eradication. The recurring issues of economic growth, peoples' participation, economic reform, equity and social development constitute the basic structures of the poverty eradication programme.

The budgets of these past five years include a series of measures designed to assist the poor and disadvantaged as part of a programme for poverty eradication. Consistent with the above themes, increased budgetary allocations were made geared towards the following:

- Sustaining the growth process;

- Increasing the poor's participation in growth and access to the benefit of growth;

- Provision of safety nets for the very poor and disadvantaged;

- Creation of institutional framework for rural development and poverty eradication;

- Modernisation of state machinery.

The Medium Term Economic Strategy for the years 2003 to 2005 represents a continuation of the plans and strategies articulated in the previous planning document, year $2000-2002$, and the various government pronouncements on the issue.

The declared emphasis in the present Medium Term Plan is "the development of a more diversified and service oriented economy, strengthening the operations of central government and poverty reduction and alleviation" (MTESP, 2003 -2005).

Government's commitment is consistent with the overall objective of poverty eradication. The Government of Grenada identified the following priorities with respect to its medium term objectives:

- Sustained robust economic growth;

- Disaster rehabilitation and improved disaster management;

- Reduced unemployment;

- Improved access to quality health care;

- Human resource development;

- Modernized state machinery;

- Improved environmental management;

- Housing development; and

- Agriculture rehabilitation.

The Government posits that advancement in the areas specified above will be enhanced through the application of new information and communication technologies and new and improved systems in both the private and public sectors including the NGO and CBO communities. 
To this end, an extensive consultation on the Poverty Eradication Strategy was elaborated. The main aim of the programme was to encourage and solicit the full and effective participation of all stakeholders into the process of determination and finalization of the strategy. It was deemed important to institute a mechanism to continuously engage civil society in the process as a necessary element in the forward planning. The process thus included a "bottom up" participatory approach at several levels including individual and sector level consultations, stakeholder level consultations, community level consultations, parish level consultations and national consultations. Annex 2 provides a detail breakdown of consultations. Various teams of local experts were engaged to carry out these consultations. Reports of each consultation were prepared and the results were infused in the overall poverty eradication programme.

\subsection{Macroeconomic Context and Progress}

The State of Grenada includes the islands of Grenada, Carriacou and Petit Martinique and several small uninhabited islands mainly along the eastern and northern coasts. The country has a land area of approximately 340 square kilometers with an estimated population of 103,532 (Year 2001 Census Preliminary Report).

The Grenadian economy is characterized by its openness, vulnerability and dependence on the international economy. In 2001, imports of goods accounted for 49.3 percent of the Gross Domestic Product while exports of goods accounted for 14.9 percent of the Gross Domestic Product. The dominant economic activity is agricultural with the production for export of bananas, cocoa and nutmegs.

Banana exports have made a valuable contribution to the economic and social development in the country throughout the 1960's to 1980's. A preferential trading arrangement with the European Union provided a ready market for the country's weekly banana exports. These earnings from bananas constituted a significant share of the income of rural households. With the dismantling of the trade regime with the advent of the WTO, banana production went into decline. In fact, in 1997 export of bananas was halted and has been marginal since then.

Cocoa and Nutmeg have been traded on the open market and invariably subjected to the vagaries of external market forces. The production and export of these traditional products have been in a state of similar decline since the 1990's.

Notwithstanding the foregoing, productions of these products constitute the mainstay of the Grenadian economy particularly in the rural economy.

There is also a large subsistence agricultural production activity mainly in the production of fruits, vegetables, flowers and mainly livestock for the domestic and regional markets. 
The Government Medium Term Economic Strategy up to the advent of Hurricane Ivan involve a series of measures aimed at economic diversification, the targeting of annual growth rates of 4 percent and the improvement in the overall competitiveness of the economy.

With the diversification initiatives, the structure of the economy is being dramatically transformed from primary agricultural production to a more service orientation. In 2001 the services sector accounted for over 70 percent of the GDP as compared with 53.2 percent of GDP in 1990 (MTESP, 2000).

\subsubsection{Economic Performance:}

The Grenadian economy has achieved relatively high rates of economic growth averaging 5.7 percent for the period 1995 to 2000. In fact, the real Gross Domestic Product (GDP) expanded by an average of 7.8 percent for the period 1998 to 1999. This relatively high growth rate must be seen against the back drop of a stagnant economy in the early 1990's which saw growth rates averaging less than 2 percent from 1990 to 1995 and 3.6 percent for the period 1995 to 1997 (MTESP, 2000; IMF Report, 2000). In 2001 there was a dramatic turn of events with the economy recording a negative growth of approximately 3.4 percent. The slowdown in the Grenadian economy in 2001 was attributed to developments in the international economy as a result of terrorist activities and its impact on world travel and trade.

The robust growth achieved over the period 1995-2000 has been attributed to expansionary fiscal policies introduced by the Government which included reform of the taxation system, expanded Government expenditure on infrastructural projects, public sector reform and economic diversification.

The overall growth has been fueled by the implementation of large construction projects; namely, the National Stadium, the Ministerial Complex, the Port Expansion Project, Road Rehabilitation and Construction Projects, Residential Housing Programmes, the Coastal Erosion Sea Defense Project, the Basic Education Reform Project and the Basic Needs Trust Fund Project.

\subsubsection{Unemployment}

The economic recovery experienced for the period 1996 - 2000 was accompanied by a significant decline in employment. In 2000, the unemployment rate was estimated at 12 percent down from 26.7 percent in 1995. The rise in employment was due to increased economic activity in the constructing, manufacturing and tourism sectors. In addition several new jobs were created in the offshore financial services sector which was introduced in 1995. The unemployment rate is highest among the youth population, women and the rural communities (MOF, 2002).

With the contraction of the economy in 2001, the unemployment rate increased to 14 percent. In 2003, unemployment rate was recorded at 13 percent (MOF. 2004). In 2004 
shortly after Hurricane Ivan, unemployment was estimated at 30 percent. In 2005 the unemployment rate is estimated at 18 percent.

\subsubsection{Inflation}

Like unemployment, inflation rates have been declining during the period 1996 - 1999 from a high of 2.8 percent in 1996 to 1.02 percent in 1999. As a consequence of increased fuel prices, inflation increased to 3.4 percent by the end of 2000. In 2001 inflation fell dramatically to 0.7 percent and by the end of 2002 the rate increase to 2.3 percent. Inflation rates have since stabilized and recorded 1.6 percent at the end of 2002 and 2004 (MOF. 2004). Following the oil price increases of 2005, inflation is expected to increase to 6 percent.

It is significant to note that the prices of food, beverages, household supplies and fuel account for about 50 percent of the consumer price index weights. The Government maintains control on the wholesale and retail markups on a range of commodities including food items, construction materials, school supplies, drugs and petroleum products. In 1998 the wholesale markups were capped at 15 percent. The range for retail markup is 10 percent to 40 percent. Most commodities however are subject to a 15 percent retail markup. Since 1997, the government has introduced a price stabilization scheme for petrol fuel. The price of a gallon of petrol was fixed at EC\$7.50. Adjustments are made in government revenue intake to reflect the changes in international price of fuel in order to keep fuel prices fixed to the consumers. Following the 2005 oil price increases the Government reexamined and reevaluated the scheme and the price of a gallon of petrol was raised to EC\$10.89.

Grenada maintains a fixed exchange rate regime with the Eastern Caribbean Dollar pegged to the US Dollar at 2.7 to 1 . Grenada remains committed to the Eastern Caribbean Currency Union established within the framework of the OECS.

\subsection{Past Policies}

From the early 1990's the Government of Grenada has embarked on several structural reform programmes which met varying levels of successes.

The major programmes instituted were the following

- Structural Adjustment Programme

- Privatization/Commercialization Programme

- Public Sector Reform Programme

- Economic Diversification Programme

\subsubsection{Structural Adjustment Programme}

In 1992 the Government of Grenada embarked on a three-year Structural Adjustment Programme designed to accelerate structural changes to reverse the deteriorating state of 
the country's finances which was adversely affecting the growth and development potential and hence poverty eradication. Grenada's annual GDP growth rate fell precipitously during the previous years.

The main goals of the programme were:

- To stimulate a real GDP growth of 4 percent in the medium term;

- To improve financial management to produce current account surpluses;

- To return the country to international credit worthiness.

The programme strategy included the following:

- Fiscal reform;

- Rationalization of public sector employment;

- Reduction of arrears of debt and contributions;

- Privatization of state owned enterprises;

- Provision of enabling environment for private sector led growth.

The debate on the outcome of the structural adjustment programme was inconclusive. The general consensus seemed to indicate that the programme had achieved some measures of success for specific parameters but in the main had a detrimental impact on economic and social development.

The programme achieved fiscal stabilization rather than structural adjustment. It was generally recognised also that the programme exacerbated the plight of the poor and did not in general improve the well being of the people. The activities implemented under the programme saw huge cuts on spending for social sector development, the provision of social infrastructure, education, training and human resource development. The programme did not enhance private sector activity in the country nor succeeded in drastically reducing the size of the public sector.

\subsubsection{Privatization/Commercialization Programme}

The Privatization/Commercialization Programme instituted by the Government achieved a high degree of success. The programme was instituted to improve fiscal management through the divestment of public enterprises to contribute to private sector growth through the transfer of assets from the public sector and to generate revenue for infrastructure development.

Several loss making Government institutions/organisations were removed as a charge on the consolidated fund. The Government successfully divested shares in the following:

- National Commercial Bank

- Grenada Bank of Commerce

- Grenada Breweries Limited 
- Grenada Electricity Services Limited

- Grenada Sugar Factory Limited

- Grenada Telephone Company

- Grenada Broadcasting Corporation

In addition, the Government of Grenada has changed the management structures of the following:

- Grenada Postal Corporation

- The Offshore Financial Sector

- The Gravel, Concrete and Emulsion Production Corporation

- The Grenada Ports Authority

- The Grenada Airports Authority

- National Water and Sewerage Authority

- Marketing and National Importing Board

- Grenada Development Bank

Negotiations are ongoing to commercialize several Government agencies and departments. These include the Government Printery, the National Parks, the T A Marryshow Community College, health sector services and several services across various ministries. The Government has also announced a policy change from long term leases of selected Government lands and buildings to outright purchases.

The proceeds of the sales of Government assets were carded for financing of capital development projects. The results of Government privatization programme show increased levels of national employment and reduction of the burden on the consolidated fund.

\subsubsection{Public Sector Reform}

The history of public sector reform in Grenada dates back to 1985 following a review of the public sector by external consultants. The review focused on the following:

- Manpower trends, forecasting and controls;

- Organisation of the public service and personnel management;

- Organisation of work and staff efficiency;

- Public policies and systems;

- Training and management development.

In 1994 a second review of the public service was undertaken. The main purpose of the second review was to ascertain the progress made in reforming the public sector from the previous initiative and to develop a plan of action that will take the reform effort forward.

The review highlighted the following achievements: 
- The establishment of the Department of Personnel and Management Services (DPMS) to oversee the reform programme.

- The equipment of the staff of DPMS to handle personnel management issues, training needs assessment and training delivery as well as to undertake the management services function.

- Securing staff reduction levels from 6633 in June 1991 to 5436 in June 1994 thus achieving the set target of 5460 by that date.

The review indicated however that the staff reduction was achieved mainly through attrition. It was also noted that the reductions have not been accompanied by corresponding reductions in the levels of expenditure on wages and salaries. In fact, the 18.1 percent reduction in staffing corresponded to 3.8 percent reduction in annual expenditure on wages and salaries. In addition, the review indicated that only limited improvement had taken place in the delivery of services.

The following major constraints were identified:

- Weaknesses in personnel management.

- Lack of role clarity among sector public servants.

- Lack of clarity on goals and objectives.

- Low performance levels.

- Lack of clarity on role of government in macroeconomic development.

Action plans were developed based on the major areas of weaknesses identified above.

The Public Sector Reform Programme is been implemented to date. The aim is to build on the successes of the past programmes and to implement the stated plan of action.

\subsubsection{Economic Diversification}

Output from the agricultural sector has been in decline during the period of the eighties and nineties and continues to decline to date.

The production of Grenada's three main export commodities, namely bananas, cocoa and nutmegs have been severely compromised for a range of reasons including marketing arrangements, low productivity, pest infestation, and changing labour force demographics.

Government's policy response included attempts at economic diversification. Renewed focus was placed on improving the productivity and marketing arrangements and production of other crops to complement the traditional exports in order to provide employment opportunities, generate income and forge greater linkages between agriculture, tourism, manufacturing and the service sectors.

In this regard, the Government embarked on the following:

- Micro and small enterprises development. 
- Establishment of financial services sector including offshore financial services.

- Liberalisation of the telecommunications sector.

- The provision of physical and social infrastructure.

- Review of incentives to manufacturing.

- Review of the Public Sector Investment Programme.

- Development of master plans, policies and programmes for tourism, forestry, environment, education and information and communication technologies.

- Development of the informatics industry.

\subsection{POVERTY SITUATION}

The Country Poverty Assessment Report (PAR) constitutes the single most comprehensive document on the socio economic status of the Grenadian economy. The report highlighted the need to develop a comprehensive database on social development initiatives and programmes undertaken by the Grenadian authorities. Prior to the completion of the Report, several area specific reports and documentation sought to address aspects of the poverty problem.

\subsection{Country Poverty Assessment}

\subsubsection{Poverty Profile}

The Poverty Assessment Report, concluded in October 1999, utilized a representative sample of the Grenadian economy and provided some critical information on the state of the country's social sector. The principal components of the study were as follows:

- A national survey of living conditions utilizing a randomly selected sample of 1124 households with 4061 individuals.

- A community situational analysis conducted in 14 communities.

- An institutional analysis of key agencies and organisations.

The survey was conducted by a team of regional experts supported by team of local officials (National Assessment Team) assembled for the expressed purpose of developing local capacity in the area of social development and poverty assessment and monitoring. The report constituted a sustained effort by the players over a two-year period beginning in 1997 following a national consultation on poverty.

The report utilized benchmark levels to determine the state of the nation's poor and arrived at absolute poverty estimates across the population. Profile included determinations on geography, age, gender, employment, education, health, housing, institutions, community development, social infrastructure and living conditions.

The report analysed the causes of poverty and provided a time phased action plan or activities aimed at poverty reduction. The conclusions of the report were subjected to 
critical rigorous analyses by the authorities, civil society and the population at large and have stood the test of time. In fact, the government has given its endorsement to the report which now forms the basis of national responses to address the attendant issues.

\section{Poverty Estimates}

The survey revealed that 32 percent of the population corresponding to 28.8 percent of households are classified as poor based on a poverty line of EC $\$ 3,262$ per annum per adult. Thirteen percent of the population, corresponding to 10.5 percent of households, are classified as indigent, being unable to meet the costs of supplying their minimum requirements for food. The study also revealed that the poor have limited access to health services, education, adequate housing and social services and that higher incidences of poverty among the youth, aged, women and female headed households and persons in the rural economy (PAR 1999).

Since the conclusion of the survey and despite Government's efforts to address the poverty condition it might be expected that with the significant downturn experienced in the economy in 2001 and 2002 that the poverty profile will not be significantly improved from the 1999 assessment.

\subsubsection{Causes of Poverty}

The demonstrated causes of poverty include economic factors and structural differential in the Grenadian economy. In addition there is a range of historical, social and psychological factors that cause poverty. The literature also indicated that natural disasters, personal catastrophe, major illnesses, differences among peoples and cultural norms can help sustain poverty or condition the interventions at its eradication

The major causes of poverty as identified in the Poverty Assessment Report are the following:

- Limited income and employment generation;

- Limited safety nets;

- Limitation of physical infrastructure (especially in rural economy);

- Weakness in social infrastructure (especially in rural economy);

- Poor community organisation;

- Gaps in institutional infrastructure;

- Limitations in human resource development.

In the Grenadian context, the major problems faced by the poor are the following:

- Lack of access to basic amenities and facilities;

- Lack of basic infrastructure;

- Inability to pay bills for basic necessities;

- Limited access to clean unpolluted water;

- Poor sanitation; 
- Poor housing;

- Lack of access to natural resources;

- Over dependence on agriculture;

- High unemployment;

- Low wages;

- Reliance or remittances from abroad;

- Persistent drug use, prostitution and alcoholism;

- Lack of credit;

- Low educational attainment.

\subsubsection{Characteristics of the Poor}

\section{Poverty and Gender}

The data from the 2001 Census indicated that the population of males and females was even. It is worthy to note that traditionally women bore the burden of poverty and have been under represented in key development areas.

Within recent years however, there has been a clear trend for improved participation by women in decision-making at the national level. The traditional occupational labels are being eroded and in recent times the term "male marginalization" has added significance.

The government has established a department of Gender and Family Affairs with the mandate to formulate a national gender equity policy and to raise awareness on the gender question. The policy will seek to entrench equity and fair treatment for women and youth on the national level and bring gender perspectives into the mainstream of the country's development agenda.

The data from the Poverty Assessment Report revealed that the poor were fairly distributed between males and females. Males account for 49 percent of poor persons and females 51 percent. The data also revealed that 33 percent of all males in the country live below the poverty line as compared with 32 percent for females.

The report also indicated that women, female headed households and children are the mostly seriously affected groups. Unemployment and underemployment are highest among the female population and a poor household is more likely to be headed by a female. In fact, the report stated that 16 percent of female headed households are unemployed and 28 percent are not classified among the labour force.

The data substantiated the notion that poor women tend to have relatively high rates of fertility and therefore poor households tend to have a relatively higher number of children.

\section{Poverty and Age}

In the Grenadian context, the youth also bears the burden of poverty and there are many problems affecting the nation's youth. A National Youth Policy and Action Plan has been 
completed and approved by Cabinet in 2001. Several activities in the plan are aimed to reverse emerging trends in youth occupation in the areas of violence, drug use, teenage pregnancies and other lifestyles.

It is evident that youth exposure to national values and anti-social lifestyles are impacting on youth social behaviour. There is a call for the development of alternative profiles for youth engagement given the high levels of unemployment and youth's aversion to traditional agricultural production. Education and skills training with the utilization of information and communication technologies are seen as worthwhile alternatives.

The data from the Poverty Assessment Report revealed a close relationship between poverty and age. Over 56 percent of the poor were less than 25 years old. In fact 51 percent of the people below the poverty line were below the age of 20 years. Children 14 years and under make up 41 percent of the poor as opposed to 28 percent of the non-poor. 5.6 percent of the poor were 61 years and older. These comprised 22.5 percent of all persons age 65 years and over.

\section{Poverty and Ethnicity}

The data revealed no discernible differences in poverty among the various ethnic groups. Persons of African decent for example comprise 80 percent of the population and 80 percent of the poor. The mixed grouping ethnic category comprises 12 percent of the population and 11 percent of the poor.

\section{Poverty and Unemployment}

The data revealed a strong association between unemployment and poverty and the poor tend to be concentrated in elementary unskilled occupations. The survey showed a National unemployment rate of 15 percent. Among the poor the unemployment rate was 20 percent as against 13 percent among the non-poor.

The unemployment rate was highest among the females and young sections of the population. The unemployment rate among the males was 10.5 percent and among the females 21.2 percent. It must be noted however that a large proportion of males were not counted in the labour force, as they were not actively seeking employment. The unemployment rate for the age group 15-19 years was shown at 41.7 percent. Apart from the government services, agriculture, construction, wholesale and retail trade and tourism sectors account for the sectors with the highest levels of employment.

The employment by major sectors gleaned from the 1998 draft labour force survey is as follows:

\section{Employment by Sector}

\begin{tabular}{|l|c|}
\hline Sector & \% Employment \\
\hline Agriculture & 13.8 \\
\hline
\end{tabular}




\begin{tabular}{|l|c|}
\hline Construction & 14.8 \\
\hline Wholesale and Retail Trade & 18.2 \\
\hline Government Services & 16.6 \\
\hline Tourism & 5.7 \\
\hline Manufacturing & 7.4 \\
\hline Transport / Communication & 5.9 \\
\hline
\end{tabular}

Source: Draft Labour Force Survey 1998

The median age for the employed was 36 years and higher levels of unemployment are concentrated in the youthful period which suggest areas for policy intervention. The labour force survey also showed that the income levels of the employed were low with the median monthly income of approximately EC\$744. The median monthly income was lower for females as against males. Male median monthly income average EC $\$ 829$, as opposed to EC $\$ 605$ for females.

The unemployment rate for the various age groups and the median monthly income are shown below.

\section{Unemployment Rate by Age Group}

\begin{tabular}{|c|c|c|c|}
\hline Age Group & \%Unemployed & Male & Female \\
\hline $15-19$ & 41.7 & 34.9 & 53.7 \\
\hline $20-24$ & 25.8 & 18.8 & 33.3 \\
\hline $25-29$ & 16.6 & 8.9 & 27.3 \\
\hline $30-34$ & 13.8 & 6.9 & 21.4 \\
\hline $35-39$ & 9.7 & 6.9 & 12.8 \\
\hline $40-44$ & 8.0 & 3.9 & 13.0 \\
\hline $45-49$ & 2.4 & 2.2 & 2.7 \\
\hline $50-54$ & 11.5 & 9.3 & 13.5 \\
\hline $55-59$ & 8.4 & 9.4 & 12.5 \\
\hline $60-64$ & 4.9 & 3.0 & 14.9 \\
\hline
\end{tabular}

Source: Labour Force Survey 1998

Unemployment is highest in many of the poor rural communities. The report indicated that unemployment ranges from 4.2 percent in Carriacou to 22 percent in St. John.

\section{The percentage of unemployment by Parish is shown as follows:}

\begin{tabular}{|l|c|}
\hline Parish & \%Unemployed \\
\hline St. George & 12.7 \\
\hline St. John & 22.0 \\
\hline St. Mark & 14.9 \\
\hline St. Patrick & 17.8 \\
\hline St. Andrew & 16.0 \\
\hline
\end{tabular}




\begin{tabular}{|l|c|}
\hline St. David & 20.5 \\
\hline Carriacou & 4.2 \\
\hline
\end{tabular}

Source Poverty Assessment Report, 1999

There has been a steady increase in the number of persons moving from rural to urban areas in search of employment and other opportunities. Employment opportunities are greatest in St. George's area and in the areas of the services sector.

The prospects for external migration have been in decline due to developments in the global economy. In fact, there has been a reversal in external movements of persons including return of national's who migrated in the late 1950's and 1960's.

\section{Geographic Distribution of Poverty}

The data revealed that the poor are evenly spread across the country with St. George, St. Patrick and St. Mark above the national average. The geographic distributions of the poor by parishes are shown in Table below.

\begin{tabular}{|l|c|c|c|}
\hline Parish & \% of Non Poor & \% Poor & \%of Parish Poor \\
\hline St. George & 28.6 & 31.7 & 34.4 \\
\hline St. John & 15.0 & 10.0 & 23.9 \\
\hline St. Mark & 4.5 & 4.8 & 33.5 \\
\hline St. Patrick & 12.0 & 14.0 & 35.5 \\
\hline St. Andrew & 25.6 & 26.6 & 32.9 \\
\hline St. David & 10.2 & 9.8 & 31.3 \\
\hline Carriacou & 4.1 & 3.1 & 26.8 \\
\hline
\end{tabular}

Source: Poverty Assessment Report, 1999

\section{Poverty and Housing}

The data revealed that house ownership is very high in Grenada, and the poor were more likely to own their home than the non-poor. It was found that 94 percent of the poor own their house as opposed to 88 percent of the non-poor. The non-poor tend to live in rented accommodation.

Approximately 71 percent of the homes in Grenada are situated on lands owned by the householder. 75 percent of the poor owned the lands on which their homes were constructed while 69 percent of the non-poor owned the lands on which their homes are located.

There is a clear relationship between socioeconomic status and housing type, with the poor housing generally of wood and galvanized zinc as roofing. The poor are less likely to have water piped into their homes and as a consequence more likely to have pit latrines as toilet facilities. Wood is the predominant source of fuel for the poor and the poor households 
have limited access to electricity, telephone and communication facilities and other social amenities. In fact the report indicated that as least 40 percent of the housing stock in the country are unfit for human habitation.

\section{Poverty and Education}

The Poverty Assessment Survey analysed the education sector and found that the educational attainment of the population is generally low with correspondingly'low level educational certification and socioeconomic status.

The data revealed that 64 percent of the population has no form of education certification and the lack of certification is higher among the poor than the non-poor. The lack of certification is also higher among the older persons in the population. In fact the data revealed that 73 percent of Grenadians aged 30 years and over have no form of educational certification.

Access to secondary and tertiary education was found to be very limited and constituted a significant barrier to the transformation of the economy to skill and knowledge based productive activities.

\section{Poverty and Health}

The data revealed no definitive evidence to suggest that in general the poor were less healthy than the non-poor. The data however suggested that the poor are more likely to contract and succumb to certain types of illnesses than the non-poor. It was further noted that the poor have lower levels of accessibility to proper health care and preventative measures and so might conceal the existence of higher levels of certain types of illnesses. The poor make greater use of public health facilities than the non-poor.

\section{Poverty and HIV/AIDS}

HIV/AIDS was diagnosed in Grenada in 1994. In 2001 there were 216 reported cases of AIDS. One hundred and six persons have since died and 110 persons are known to be living with the virus. The data shows that there are $15-20$ new cases each year. It must be noted however that the reporting mechanism is suspect and there may be many cases of persons living with the disease which are not part of the official statistics. Of the number of reported cases, 138 persons were males and 78 persons were females. With respect to persons living with the disease, 64 are males and 36 are females. The disease is most prevalent between the age group of $15-54$. One hundred and eighty seven (or 87 percent) of the reported cases fall within the $15-54$ age group. Seven cases were reported with respect to persons born with the virus.

The linkage between HIV/AIDS and poverty is evident. The disease impacts negatively on productivity, health care expenditure, income generation, human capital formation, living standards and social behaviour. HIV/AIDS can cause individuals and households to become poor or to intensify existing poverty situations among the poor. 


\section{Poverty and Living Conditions}

The report indicated that there is a tremendous difficulty to break the poverty trap and as a consequence poverty moves from generation to generation. Alcoholism, drug abuse, crime, prostitution, praedial larceny and several manifestations or anti-social behavior are rampant among the poor.

With respect to access to basic utilities, for example water, the survey found that 21 percent of poor households have no close access to water and only 8 percent have water piped in the yard of their residence. 75 percent of poor use pit latrines and many have no toilet facilities whatsoever.

Poor housing and environmental standards are also characteristics of the poor. Additionally, over crowding is also a feature of poor households. The report noted the importance of the agricultural sector to the well being of the rural people and also noted the significance of the fall in the production of bananas on the lives of the rural poor communities.

\section{Poverty and Institutions}

The report indicated significant capacity constraints with respect to institutions with a poverty eradication focus. The report called for the establishment of institutions with resources for promoting sustainable development and poverty eradication.

Community development remains a major focus of the Government of Grenada and in fact is the expressed mandate of several civil society organisations. The Government has established a Community Development Division which aims to improve the social infrastructure of communities especially in the rural communities. A rural development policy document has been prepared and submitted for comments from civil society organisations. Within the medium term, the Government plans to implement human resource development training for community groups and to actively support small and micro enterprise development. To this end, there are plans to establish a rural development commission and a micro enterprise development board. Plans are also afoot to establish a rural development fund.

Despite the foregoing, analysis of the functioning of the Division reveals significant inadequacies in the types and levels of resources to promote poverty eradication. The Division's scope of activities are geared to reduce the incidences of poverty on a limited basis and do not constitute a long-term vision for poverty eradication.

The activities of civil society in the area of community development are also geared to reduce the incidences of poverty rather than part of a long-term strategy for poverty eradication. Lack of resources and low levels of cooperation and coordination among the actors do not permit meaningful actions for eradicating poverty on the national level. 


\subsubsection{Poverty and Coordination}

\section{Government Agencies}

Several ministries are charged with the responsibility of overseeing government's social sector spending. These include:

- Ministry of Education

- Ministry of Housing, Social Services and Culture

- Ministry of Health and the Environment

- Ministry of Youth, Sports and Community Development

- Ministry of Tourism, Women's Affairs and Social Security

- The Prime Minister's Office

Coordination among the above is a desired objective.

\section{Civil Society Organisations}

In addition several civil society organizations are actively involved in the provision of social services.

Principal among them are the following:

- Agency for Rural Transformation

- Grenada Community Development Agency (GRENCODA)

- Child Welfare Authority

- Church Forum for Social Action

- Conference of Churches, Grenada

- Early Childhood Education Connection (ECE)

- Grenada Food and Nutrition Council (GFNC)

- Grenada Girl Guides Association

- Grenada Media Workers Association

- Grenada National Council for the Disabled (GNCD)

- Grenada National Organisation for Women (GNOW)

- Grenada Planned Parenthood Association (GPPA)

- Grenada Save the Children Development Agency (GRENSAVE)

- Grenada Union of Teachers (GUT)

- Legal Aid and Counseling Clinic (LACC)

- NCH Action for Children

- New Life Organisation (NEWLO)

- Grenada Citizen Advise and Small Business Agency (GRENCASE)

- Grenada Boys Scouts Association

- Extended Care Through Hope and Optimism (ECHO) 
A case can be made for improved coordination among these agencies and between those agencies and government.

Eight NGOs have organized themselves into an umbrella body called the Interagency Group of Development Organisation (IAGDO) with the aim of enhancing levels of cooperation and collaboration among them.

\subsubsection{Policy Recommendations}

Policy recommendations from analysis of Poverty Assessment Information are as follows:

- Poverty eradication programme must be appropriately targeted at youth, women headed households, large household, the rural economy and specified spatial vulnerable and marginalized groups.

- Specific programmes must target both males and females to avoid the problem of male marginalization and vulnerability.

- Specific focus must be given to the creation of employment opportunities.

- Specific focus on the improvement in the social infrastructure.

- Specific focus must be given to health, education, water and social amenities.

- A review and rationalization of the safety net programme must be completed.

- Full and effective participation of civil society must be encouraged and actively promoted.

- A programme of public awareness and public education must be established and sustained.

- A review of the planning structure must be conducted and pro poor mechanism integrated in national planning.

- Capacity building programme must be established and mechanisms for management, evaluation and monitoring of poverty instituted.

- Meaningful involvement of the private sector, NGOs CBOs, FBOs are critical to the process of poverty reduction.

- Reform of the agricultural sector is necessary to promote employment.

- Poverty eradication programme must be rooted in the community to facilitate ownership and sustainability.

- The Government must provide the enabling environment and attendant political will for sustained programming.

- Special focus must be given to agricultural reform and the impact of external trade relations and the mitigation of exogenous factors.

\subsection{The Core Welfare Indicators Questionnaire Survey}

In 2005 following the impact of Hurricane Ivan and Emily, the Government commissioned a Core Welfare Indicator's Questionnaire (CWIQ) Survey.

The CWIQ is a household survey that measures changes in key social indicators for different population groups - specifically indicators of access, utilization and satisfaction with core social and economic services. It is a very effective tool for improving project and 
sector programme design and the targeting of services towards the poor and most disadvantaged communities. When repeated annually, the CWIQ becomes a monitoring tool for assessing implementation effectiveness and the impact of programs/projects on living conditions. The CWIQ is being used increasingly as one of the key tools for monitoring PRSPs.

The CWIQ was required to produce information leading to:

- Clearer details and statistics on the impacts on women by the specific analysis of the data for gender;

- Details on children and their living conditions; and

- Detailed analysis of the social vulnerability implications of the disaster.

The survey was implemented over a four-week period in May and June 2005.

The Grenada Core Welfare Indicators Questionnaire (CWIQ) Survey Report reflects the challenge of measurement in Grenada, made more urgent by the passage of Hurricanes Ivan and Emily, which created additional need for services while reducing both the services available and access to the information needed to provide the services. The CWIQ Survey also helped to define key social indicators; develop a simple and quick survey instrument for monitoring ongoing changes in living conditions; and encouraged wider dialogue and participation among a wider range of interests.

In the Grenadian context, the questionnaire was adapted to capture the effects of Hurricanes Ivan and Emily, providing the first real systematic study of the devastation caused by the hurricanes.

According to the survey, overall nearly ninety percent of dwellings in the country were damaged, with half sustaining serious damages and approximately 5 percent of dwellings being completely destroyed. The highest levels of damage to dwellings occurred in St. George's, St. David's, St. Patrick's and St. Andrew's. The poorest households were the most adversely affected, with 95 percent suffering damages as compared to 65 percent in the least poor group. Damage was also more severe among the poor.

Almost half of households across Grenada were displaced, just over half for several days only, 24 percent for several weeks, and 13 percent for several months. Some 7 percent were still displaced seven months after hurricane Ivan. Most displaced households moved to family and friends for shelter.

Only 10 percent of damaged households had some insurance, with none among the poorest quintile. Home insurance was most evident in St. George's. Over a third of damaged households are being rebuilt. Half of the householders who are rebuilding are aware of the building codes and among those who are aware, nearly all are complying with the codes. 
About 75 percent of households have received support post-Ivan, with the family being the most important source of help. The most common forms of support received were food and water, and building materials.

Physical injuries and mental sickness respectively occurred in less than 10 percent of the households. Most physical patients have recovered but less than one quarter of the mentally affected have recovered.

Damage to key assets was highly variable. Ten percent of vehicles were damaged, half of them severely. Damage to tree and cash/short crops were significant and severe but damage to livestock was minimal. Recovery has been variable.

Earnings have fallen, especially from wage employment, through loss of jobs and the reduction of salaries. Income from business fell by 15 percent. The disaster also had an impact on nutrition, and affected the capacity of individuals to bounce back. Food security has also been compromised through increased food imports and the loss of the nutmeg and cocoa industries, which have also affected the national economy.

The CWIQ reaffirmed several of the recommendations of the Poverty Assessment Survey. Specifically the survey revealed that just under half of the households in Grenada are female-headed, with more than one fifth in the rural areas falling into the lowest welfare quintile. Well over half the female heads are unemployed, as compared with one quarter of male heads. Similarly half the female heads are not in marital union as compared with one quarter of male heads of households. Male heads of households account for the vast majority employed in the private formal sector, and of persons who are self-employed. Female heads of household predominate in the private informal sector. A significantly large proportion of households within the bottom quintile of the rural households are female-headed, compared with households where most households are men. For urban households, 24 percent of female heads lives in the bottom 3 quintiles as opposed to a mere 18 percent for the males. The dependency ratio is fifty percent or higher in all parishes and the highest ratios are found among the unemployed and in the private informal sector. The dependency ratio is higher for female-headed households than for male.

With respect to access to education, the survey revealed that less than half of households have access to schools. This number falls to 24 percent for secondary schools. Urban households have easy access while less than 30 percent of poor students from rural areas do.

Access to health care is also found to be restricted for the poor. The survey revealed that in urban areas, 68 percent of the populations have a health facility within 15 minutes, compared with 30 percent for the rural population.

Unemployment is another key statistic. The survey revealed that some two thirds of the population was in the active population (labour force), with 81 percent employed. Unemployment is highest among the poor, and among the 15-29 year olds of both sexes. Paid employees and the self-employed respectively make up the great majority of the 
employed population, with males making up the larger percentage in each case. Selfemployment is highest in parishes best known for fishing. Private enterprise employs the highest percentage of workers and more males than females. More females than males are employed in the public sector. The highest levels of employment are found in construction and services. Employment still falls along traditional gender lines, best illustrated in the construction, wholesale and retail, and hotel and restaurant sectors. The total unemployment rate is $18.8 \%$, higher among women than men. In the urban area, female unemployment is more than double the male rate. Nearly one third of youth are' unemployed, again with higher rates among females.

In large measure, and based on these select parameters of access to basic services and level of employment, the poverty condition in the country has been exacerbated as a direct result of Hurricanes Ivan and Emily. The hurricanes have in fact reversed several of the gains that were made since after the elaboration of the Poverty Assessment Survey. The Government had in fact introduced several initiatives aimed at poverty eradication.

\subsection{CURRENT EFFORTS AT POVERTY ERADICATION}

Current poverty eradication efforts are driven by the Government in collaboration with international organization and civil society groups. In the main, these Projects received financial support from the international community. Direct budget allocations account for a small proportion of the total expenditure. It must be noted however that civil society organizations especially the NGO community are engaged in several self-initiated programmes aimed at poverty eradication. Although these projects are generally small and under funded, these NGO Projects tend to make a significant contribution by directly targeting the poor communities. Indeed the NGO community has acquired the capacity to utilize small amounts of resources to address the poverty condition. Civil society direct involvement is a necessary condition for advancing poverty eradication goals in Grenada.

Current Poverty Eradication Projects include the following:

- Grenada Rural Enterprise Project (GREP)

- Disaster Management and Preparedness

- Food Security Project

- Biodiversity Conservation and Protection

- Climate Change and climate vulnerability

- Project to Combat Land Degradation

- Infrastructure and Road Building Programme

- Health Sector Reform

- Education Reform

- Public Sector Reform / Human Resource Development

- Information, Communication and Technology Project

- Project to Combat Drug Use, Crime and Anti social Behaviour

- Renewable Energy Project 
- National Physical Development Plan

- Capacity Building and Institutional Strengthening

- Microenterprise Project

- Good Governance Project

- Employment Generation Project

- Agricultural Diversification Project

- Solid Waste Management Project

- Affordable Housing and Shelter Project

- Basic Needs Trust Fund (BNTF)

- Legal Aid and Counseling Programme

- Family Planning Project

- Community based Institutional Strengthening Projects

- Water of Life Project

- Research study on Social Protection and Poverty Reduction in the Caribbean

A synopsis of some of these projects is outlined below:

\subsection{Grenada Rural Enterprise Project (GREP)}

Objectives: The main objectives of the Grenada Rural Enterprise Project is to reduce rural poverty in a sustainable and gender equitable manner by offering rural households a chance to enhance their income through the realization of economic activities.

Activities: The Project activities include the following:

- Diversification and improvement of income generating activities.

- Strengthening capacity and building confidence at the at the rural community level.

- Strengthening of rural service providers to meet community needs. - Promoting efficient and environmentally sustainable production and processing
activities.

- Fostering sector and market linkages.

Output: The Project envisages the following outputs:

- Improved access to support services and facilities.

- Enhanced business activities

- Increased rural incomes

- Higher levels of entrepreneurship, technical and managerial skills.

- Increased flow of funds from financial intermediaries.

- Increased participation in local organizations and activities.

- Increased access to social services.

- Increased levels of numeracy and literacy.

- Increased educational and skills levels especially of the young.

- Reduction in unemployment levels.

- Strengthened community groups and increased capacity among executing agencies.

- Improved capacities within financial intermediaries to service the rural households. 
- Improved capacity within the Ministry of Agriculture to provide technical support to farmers and rural production units.

- Improved land holdings and improved productivity leading to higher farm incomes.

- Pilot production activities to serve as best practice examples.

- Higher standards of products produced in the rural areas.

- Enhanced access to markets for rural production.

Problems Encountered: The major problems encountered include the following:

- Delay in finalization of logistics arrangements for the Project.

- Absence of required baseline data.

- Bureaucratic delays in accessing resources for Project implementation.

- Delays in Project implementation

\subsection{Disaster Preparedness and Management}

Objectives: The objectives of the Disaster Preparedness and Management Project are to strengthen the national disaster response capacity and to strengthen Grenada's resilience and preparedness to tackle disasters through institutional strengthening and mitigation measures.

Activities: The project activities are as follows:

- Implement mitigation and strengthening measures aimed at minimizing damage caused by disasters and reducing the disruption of economic activities in the event of emergencies.

- Establish sustainable procedures to ensure quick response in the event of natural disasters.

- Define and implement a national hazard mitigation strategy based on strengthening institutional capacity to prepare for and respond to disaster emergencies, in particular through the strengthening of the national disaster office.

- Institutional strengthening, aimed at improving Grenada's capacity to prepare for and respond to disaster emergencies through technical assistance, capacity building and training, rehabilitation of shelters and the Emergency Operations Center (EOC), and procurement of necessary emergency equipment and supplies.

- Physical mitigation, aimed at minimizing damages caused by disasters through preventative infrastructure investments and associated supervision services as well as the necessary preliminary studies to assess risks and damages, and prepare detailed designs for critical priorities to be subsequently financed.

Output: The project outputs are as follows:

- Operation of emergency procedures and instituted internationally accepted standards

- Capacity enhancement for disaster management

- Trained personnel in field

- Construction of physical infrastructure

- Increased levels of personnel in disaster management. 
Problems Encountered: The major problems encountered are as follows:

- Bureaucratic delays in implementation

- Lack of adequate integration of disaster issue in national planning

- Lack of resources to establish disaster management fund

- Inadequacy of baseline information.

- Capacity limitations

\subsection{Food Security Project}

Objectives: The objective of the food security programme is to enhance food security and nutritional status of rural households.

Activities: The Project is implemented by the NGO community and involves a range of activities in the following:

- Backyard gardening

- Fruit presentation

- Livestock production

- Agriculture training

- Food security awareness

- Monitoring and evaluation

Output: The Project outputs are as follows:

- Documentation of baseline data

- Trained rural households

- Enhanced infrastructure for food security

- Community empowerment

- Public awareness programme conducted.

Problems Encountered: The food security project was seen as a most appropriate project focused at poverty eradication. The problems encountered during implementation were as follows:

- Limited financial resources

- Significant delays due to various capacity constraints

- Lack of adequate supplies

\subsection{Biodiversity}

Objectives: The objective of the Project is the fulfillment of Grenada's obligation under the Convention of Biological Diversity and to promote the Country's efforts at achieving sustainable management of its biological resources.

Activities: The activities of the Project included the following: 
- Assessment of key sectors for biological diversity - agriculture, forestry, wild life, fisheries, marine and coastal areas, land use and environmental planning and tourism.

- Identification of gaps for effective management of natural resources.

- Assessment of institutional, policy and legal frameworks for planning and management.

Output: The major outputs are as follows:

- Determination of capacity needs for biodiversity conservation and protection.

- Provision of broad-base support for conservation and sustainable use of biodiversity.

- Protection of key eco-systems from negative human induced impacts.

- Development and encouragement of sustainable utilization of biological resources that are essential to the livelihood of local communities.

- Maintenance, recovery and promotion of genetic resources necessary for sustainable agriculture.

- Ensurance of a fair and equitable sharing of the benefits arising out of the utilization of genetic and ecosystem resources.

- Elaboration of National Biodiversity Strategy and Action Plan (NBSAP).

- Provide information on key ecosystems for incorporation into national accounts and decisions on national development projects.

Problems Encountered: The major problems encountered include the following:

- The urgent need to develop a national policy for guiding land management (including a land use policy, and a national physical development plan) and incentives for protection of critical ecosystem.

- Lack of implementation of appropriate policies which contribute to the conservation of aspects of biodiversity and the need to modify policies with significant negative impacts on the environment.

- Lack of effective enforcement of existing legislation and at mitigating the adverse impact on environment due to human behavior.

- Legislative revision for improved regulation of activities with significant adverse impacts on the integrity of key habitats and on resident and migratory species.

- Lack of effective enforcement of existing legislation and at mitigating the adverse impact on the integrity of key habitats and on resident and migratory species.

- The need to build awareness on and understanding of the value, sustainable use, and the need or immediate conservation of natural resources by decision makers and stakeholders.

- Lack of comprehensive and up to date baseline biological/environmental data and inventories on key species and habitats.

- The need to develop management plans for key ecosystems, biological and genetic resources.

- Institutional strengthening for key agencies with responsibility for management of biological resources. 
- Genuine collaborative mechanism among state agencies, and between state agencies and stakeholders for joint management of environmental resources.

- The need to develop a local repository for representative samples of flora and fauna.

- The need to incorporate environmental costs into the planning process.

\subsection{Climate Change}

Objectives: The Project objectives include the fulfillment of Grenada's commitments under the United Nations Framework Convention on Climate Change which includes the stabilization of green house gas concentration in the atmosphere and the institution of mitigation measures to counter the potential impacts of global climate change.

Activities: The Project activities included the following:

- An inventory of emissions of green house gasses by sources

- An initial analysis of Grenada's vulnerability to the adverse impacts of climate change

- Proposed national measures aimed at fulfilling Grenada's commitments under the UNFCCC.

- Elaboration of National Report on Climate Change

Output: The Project output includes the following:

- National inventory of anthropogenic emissions by sources and removal by sinks of GHG.

- Institution of appropriate measures to eliminate data gaps on baseline information.

- Regional collaboration in the development of emission factors.

- Assessment of current levels of Grenada's vulnerability to the effects of climate change.

- Identification of existing information gaps.

Problems Encountered: The major problem encountered is the lack of national capacities to address the attendant issues. The priorities recommended to address this constraint include the following:

- Strengthening of the Institutional Framework, which include;

- The establishment of a coordinated mechanism for environmental management, including climate change;

- The strengthening of the legal frameworks, including building codes to provide for management of climate change issues;

- The strengthening of the technical capacity within the country, through training of appropriate personnel, to address climate change issues

- Strengthening of the data collection and monitoring systems to facilitate the collection and analysis of data relevant to climate change. This will be applicable to all sectors of the economy that are sensitive to the impacts of climate change. 
- Public Awareness and Education on Climate Change in general and the role of the individual in mitigating and adapting to climate change.

- Special efforts are needed to begin the collection of as much baseline data as possible, in order to improve future analyses to guide national planning and development.

\subsection{Land Degradation}

Objectives: The objective of the project is to fulfill Grenada's obligation under the United Nations' Convention to Combat Desertification. A specific objective is to combat desertification and mitigate the effects of drought through effective action in the framework of an integrated approach consistent with Agenda 21.

Activities: The project includes the following:

- Give priority to combating desertification and mitigating the effects of drought and allocate adequate resources;

- Establish strategies and priorities within the framework of sustainable development plans and / or policies to combat desertification and mitigate the effects of drought;

- Address the underlying causes of desertification and pay attention to socioeconomic factors contributing to desertification process;

- Promote awareness to facilitate the participation of local populations in efforts to combat desertification and mitigate the effects of drought;

- Strengthening of appropriate existing relevant legislation, enacting new laws and establish long-term policies and action programmes.

Output: The project outputs are as follows:

- Establishment of institutional structures for management

- Mechanisms developed for facilitating civil society participation

- Collaborative and cooperative mechanisms established

- Forestry tree planting programme established

- Monitoring mechanisms established

- Improvement in human capital.

Problems Encountered: The major problems encountered are as follows:

- Lack of adequate institutional arrangements

- Capacity and resource limitations

- Lack of stakeholder participation, ownership and public education and awareness of the issue.

\subsection{Health Sector Reform}


Objectives: The provision of adequate accessible, affordable and equitable health services and the maintenance of a protected environment.

\section{Activities:}

- The establishment of an autonomous body to manage hospital services

- The establishment of an autonomous body to manage solid waste collection and disposal

- Reorganization of primary health care

- Promotion of health care financing

- The development of institutional capacity

- The development of physical capacity

- The development of human resources.

Output: The programme outputs are as follows:

- Creation and functioning of autonomous bodies

- Decentralized primary health care system

- Increased financing for health

- Establishment of functioning institutions and facilities

- Increase number and improved quality of health care providers.

Problems Encountered: The major problems encountered are as follows:

- Lack of stakeholders buy-in to the reform effort

- Union activity resulting in delays

- Lack of resources to underwrite the reform effort

- Worker uncertainty for the new environment.

\subsection{Health and Nutrition}

Objectives: The Medium Term Economic Strategy calls for a strategy to ensure that Grenada citizens are provided with appropriate, affordable and accessible health care in a healthy environment. This includes developing of quality health care to all citizens, improved health facilities, reducing in the prevalence of HIV/AIDS and health sector reforms.

Activities: The following strategies and measures were advanced:

- Improve supply of safe drinking water

- Develop a five year strategic health plan

- Revision of health legislation

- Expand universal immunisation Programme

- Improve health service delivery mechanisms

- Reintroduce/ strengthen school feeding programme

- Intensify health education programmes in primary and secondary schools

- Ensure the supply of low cost generic aids drugs

- Intensify Aids education programmes 
- Strengthen AIDS and expand $\mathrm{MCH}$, reproductive and family planning activities

- Intensify community awareness of healthy eating and lifestyles

- Train health administrators in health administration principles

- Upgrade and rehabilitate all community clinics

- Construction of major clinic in St. George's

- Complete new General Hospital

- Introduce National Health Insurance Programme

Problems Encountered: The major problems encountered include the following:

- Political interference and union activities

- Resistance to change

- Worker uncertainty in new environment

\subsection{Education Reform}

Education constitutes a main element of Grenada's Poverty Eradication Strategy. To this end, the Government elaborated a Strategic Plan for Educational Enhancement and Development (SPEED) $2002-2010$.

The project was designed to be consistent with the Government's Medium Term Economy Strategy and findings of the Poverty Assessment Report. In fact, the Poverty Report declared that "Grenada's salvation for poverty in the new global dispensation depends critically on the knowledge and skills Grenadian possess" (Poverty Assessment Report pg. XVII).

Objectives: The overreaching the objective of the strategic plan for education is to develop a learning society through effective enhancement of Grenada's human resource. To this end, the project involves the following:

- Provision of universal access to education

- Improvement of the quality of education and the achievement of pupils.

- Provision of learners with relevant knowledge, attitudes and skills.

- Establishment and strengthening relationships with partners in education.

- Improvement of the effectiveness of management and administration of education at ministry and school levels.

- Ensurance of consistent government financing of education, to diversify the funding sources and to make certain that resources are used efficiently.

The project overall objective is to improve the efficiency and effectiveness of the education system and enhancing the quality and equality of access to basic education.

Strategies and Measures: The Plan's strategies and measures includes the following:

- Achieve universal access to primary education by 2003

- Universal access to secondary education in the medium term

- Expand access to tertiary education.

- Strengthen monitoring of truancy 
- Establish/upgrade TVET centres

- Modernise and upgrade all educational facilities

- Increase use of computers in schools

- Establish functioning learning resource centres in primary and secondary schools

- Improve teacher training and development instruments relating to professional teaching standards

- Review conditions of teaching service

- Develop an improved teacher supervision system

- Develop a competency based approach to the evaluation of learning at primary and secondary levels

- Strengthen continuous assessment at primary and secondary level.

- Train teachers in diversified testing methods.

- Total revision of education curricula

- Establish a comprehensive Tec Voc programme that responds to HRD needs

- Develop secondary and tertiary level programmes that responds to labour market requirements

- Develop Labour Market Information System

- Enact and enforce revised education act

- Establish fully functioning school boards

- Establish fully functioning Parent Teacher Associations

- Engage the media in promoting education

- Improve working relationship with national, regional and international organisations.

- Monitor annual education budget

Output: The major outputs include the following:

- Construction of new Ministry of Education Head Office

- Restructure management

- Improved supervision and management

- Improved curriculum design and implementation

- Construction and rehabilitation of schools

- Increased secondary places in underserved districts

Problems Encountered: The major problems encountered were as follows:

- Bureaucratic delays due to management and capacity constraints

- Poor supervision on project implementation

- Political interference

- Resistance to institute a culture of reform with poverty focus at all levels

- Unwillingness to change existing status quo.

\subsection{National Physical Development Plan}


Objectives: The primary objective of the plan is to provide an integrated and coherent framework to promote and guide spatial and physical development activity in Grenada in a sustainable manner.

The strategic objectives of this plan represent a comprehensive socio- economic framework for the formulation of development objectives, policies and proposals in the national physical development plan. Also, the plan presents a spatial development strategy to guide the implementation of socio economic policies such as housing programmes, retention of good agricultural lands and decentralization of industrial development lands.

Activities: The planned activities include the following:

- The formulation of land use and project proposals that would be complementary to current socio-economic policies and proposals for national development.

- The provision of a strategic planning framework to facilitate:

- Rational allocation of the land resource among competing uses and interest

- Consistency in the regulation and control of development activity More detailed level planning at the national and sub-national levels

- Adoption and implementation of appropriate development policies and projects in order to:

- Maintain the ecological integrity of the biophysical environment;

- Maintain the integrity of the cultural landscape including traditional economic activities (agriculture, forestry), significant historical and archeological sites and the form and character of urban and village development;

- Safeguard suitable lands for affordable housing, viable agriculture and environmentally sensitive tourism and industrial development;

- Control the demands on the infrastructure systems (water supply, waste disposal, transportation facilities etc.) and ensure efficient use of existing and proposed systems;

- Safeguard population, housing, economic activity and infrastructure facilities from climatic and seismic hazards.

- Promotion of efficient and timely development and coordination of the programmes and investments activities of individual public and private sector agencies involved in development.

- Provision of a basis for community participation in the planning and development process, as was initiated in the preparation of the Carriacou-Petite Martinique Development Plan

Output: The National Physical Development Plan is conceived as a medium to long term plan with a twenty (20) year perspective. The plan comprises a diagnosis of key development issues and outlines a strategic vision and development objectives for future development activity as well as a basic spatial development concept and sectoral and area policies and proposals. The plan is expected to provide the following benefits:

- Serve as a planning framework by the Physical Planning Unit of the Ministry of Finance to facilitate the efficient and effective coordination of development programmes and projects. 
- Provide a sound base to government for the administration of funding ad technical assistance for planning and development matters.

- Provide the appropriate legal regulatory framework for sustainable development.

- Serve as a guide to donor agencies and financial institutions with regard to a comprehensive spatial development strategy, project possibilities and action plan thus resulting in an increase in the level of confidence by investors and developers in making strategic land use and investment decisions.

Problems Encountered: Among the challenges and constraints and which are of strategic importance thus requiring focused attention included:

- The development pattern in the country is characterized by the concentration of community facilities, business activities and employment opportunities in the greater St. George's Urban Area in southwest Grenada. The development disparities between the St. George's Urban Area and the other settlements are influencing patterns of rural to urban migration resulting in congestion and other environmental impacts in the primary center.

- Certain demographic trends present implications for rural development and management of development pressures in the Greater St. George's Urban Area. These trends include:

- The implications for rural development and the management of development pressures in the Greater St. George's urban area

- Consistent reduction in the average size of households in the country and the resultant increasing demand for housing.

- The lack of adequately human resources to effectively implementing the plan was also noted as a major constraint in this regard

- The stable economic development as well as economic growth experienced during the mid 1990s has caused some level of concerns from a physical planning perspective. This include:

- The relative absence of effective linkages between economic planning and physical planning;

- Weak linkages among the major economic sectors and the implication for balanced sectoral and spatial development;

- The concentration of economic activity and jobs in the greater St. George's areas and the problem of poverty and its implication for the provision of housing and other social development facilities;

- The management of human impact on the environment arising from activities such as squatting and spontaneous development.

\subsection{Capacity Building and Institutional Strengthening}

Objectives: The development objective is to promote and accelerate sustainable human development through the design and completion of economic and social programmes and interventions to improve individual and community welfare.

Activities: The Project activities include the following: 
- Development of criteria classification system design databases and execute questionnaires and surveys to analyse the existing skills training programmes for youth development.

- Assessment of skills requirement in the private sector and identify opportunities for youth development.

- Identification and formulation of programmes and initiatives designed to improve the status of youths and women.

Output: The project output includes the following:

- User friendly database of types and levels of skill training programmes for youth and women;

- Detailed time phased manpower resource plan linking identified needs and the requirements of the job market;

- A National Strategic Plan and Programme of Action for youth and women development.

\section{Problems Encountered:}

- Political interference

- Implementation delays

- Lack of community ownership

- Lack of appropriate management strategies

\subsection{Basic Needs Trust Fund (BNTF)}

Objectives: The Government of Grenada has recently launched on the Fifth Phase of the BNTF. The major objective of the BNTF 5 is to achieve Poverty reduction and sustainability in poor communities.

The BNTF programme (BNTF 1 - BNTF 4) has been an integral part of the country's social development agenda. Apart from the inflow of foreign exchange via the grant window for basic infrastructure, the programme provided needed support in the areas of training and employment generation and assisted in strengthening local communities. The programme facilitated the empowerment of the local communities including improved organization capacity and assisted in community mobilization and encouragement of community ownership.

Activities: BNTF 5 involves establishment of basic social infrastructure in the following subsections:

- Water and Sanitation: Water reservoirs/tanks and distribution lines constructed/extended to provide potable water. Construction or refurbishment of public toilet/bathing/laundry facilities in remote communities that do not have a pipe-borne water supply.

- Education: Construction, upgrading and extension of school buildings, including new or expanded pre-school and day-care facilities. 
- Health: Construction and rehabilitation of primary health clinics and community hospitals.

- Physical Welfare of Vulnerable Persons: Construction, rehabilitation or extension of facilities that enhance the physical environment of the elderly, the infirm or children at risk.

- Community Markets: Construction or rehabilitation of community/craft markets, and other activities that support productive ventures.

- Access: Rural roads, drains and footpaths constructed or upgrade to provide continuous all-weather usage to mitigate flooding and soil erosion.

- Maintenance: This component will be used to assist beneficiaries with the maintenance of public facilities in the education, health and community sectors.

Output: The Project output includes the following:

- Physical evidence of completed infrastructure

- Improvement development, development of skills set in rural communities

- Improvement in early capacities of rural communities

- Strengthening of community organization.

Problems Encountered: The major problems encountered in previous vintages of the BNTF include the following:

- Lack of programme flexibility

- Lack of national capacities for project implementation

- Bureaucratic delays

- Lack of proper control and management systems

- Inadequate levels of social inclusion of poor people in national decision- making

In response to some of the issues stated above, BNTF 5 will constitute a more holistic approach to rural and local community development. The approach will examine the total needs of the communities within the framework of the Poverty Eradication Strategy.

BNTF 5 will place greater emphasis on community participation and community ownership. Particular attention will be placed on targeting of resources to ensure that the poorest are the ones to benefit. The programme also envisages greater cooperation and collaboration among the various stakeholders including wide ranging consultations on dialogue on the relevant issues.

\subsection{Grenada HIV/AIDS Prevention and Control Project}

Objectives: The main objective of the HIV/AIDS Prevention and Control Project is to reduce reported HIV/AIDS cases by 50 percent and to reduce mortality and morbidity attributed to HIV/AIDS by 40 percent in 5 years. The project also aims to improve the quality of life of persons living with the Virus and to consolidate sustainable organizational framework for managing AIDS.

Activities: The Project activities are as follows: 
- Expansion of the available options and infrastructure for care and treatment of persons living with AIDS.

- Development of system of reporting, tracking and monitoring of AIDS cases.

- Establish clinical preventative intervention measures and support systems.

- Institute legislation and regulatory reforms.

- Establish programme of training and education on HIV/AIDS and public awareness aimed at modifying attitudes and sexual practices.

Output: The Project output includes the following:

- Establishment of health status indicators.

- Establishing of infrastructure and systems.

- Establishment of national response management support structure.

- Changes in attitudes towards persons living with the disease.

- Reduction in number of HIV/AIDS cases.

\section{Problem Encountered:}

- Bureaucratic delays in project implementation

- Absence of framework for project execution.

- Untimely provision of resources.

- National resistance to deal with HIV/AIDS due to various levels of uncertainty.

\subsection{Social Safety Net Measures in the 2006 Budget}

The 2006 budget includes new measures to help the most vulnerable segments of society challenged by recent developments. The Government opined that long-term social development efforts need to be supplemented by targeted social safety net measures. In this regard, the 2006 budget will include the following:

- An increase in the monthly transfer to needy elderly persons, mainly in rural areas, from EC $\$ 100$ to EC $\$ 150$ at a budgeted annual cost of about EC $\$ 4$ million;

- A scheme to temporarily subsidize the increase in bus fares for about 2,000 tertiary students at a budgeted cost of EC $\$ 1-1.5$ million. Given the seemingly permanent nature of the increase in international oil prices, this subsidy will be phased out over time;

- Other social programmes for the vulnerable members of society such as free water supply; free books and uniforms for needy children, free medicine for the elderly will be continued.

\subsection{Current Programmes - Conclusion}

The foregoing programmes, while addressing issues relating to poverty, are not all necessarily and specifically geared to poverty eradication. In fact, for several of these programmes, the GREP and BNTF being noticeable exceptions, poverty eradication has turned out be merely incidental. In the main, many programmes - although with laudable objectives - are often not appropriately targeted and not properly focused at poverty eradication. An Audit of the programmes revealed a general lack of specificity and 
prioritization in the face of scarcity of resources In sum, it is intended to review these programs on the basis of the forthcoming poverty strategy, to streamline them if and where necessary, so as to increase the efficiency of resource allocation in the fight against poverty.

Capacity constraints leading to significant and costly delays in project implementation are characteristic of several projects. It is evident that limited human, technical and institutional capacities and the attendant lack of real focus on poverty undermine the integrity of achieving the various project objectives.

Several projects can be further disaggregated to indicate shorter term, easily measurable and verifiable outputs. Proper project design and management structures must be instituted with sufficient flexibility to allow for adequate delegation of authority.

A strategic approach will have to rely on explicit references to targets for poverty eradication, committed resources, implementation modalities, mechanisms for monitoring, and impact evaluation. The programmes should be sufficiently disaggregated to allow analysis at minute levels of detail. A holistic approach is intended to lend to the full and effective participation of the citizenry. Finally, the programmes should be time-bound and will be assessed against measurable indicators at various levels and stages of implementation.

\subsection{NATIONAL POVERTY ERADICATION STRATEGY}

\subsection{Vision}

The overall vision of the Government to address the poverty condition in Grenada is to return the economy on a path of sustained economic growth.

The Government aims to promote various initiatives to develop a more diversified and service oriented economy, to involve all stakeholders in the development thrust, to strengthen the operations of central government, and to eradicate poverty among its citizenry.

Grenada subscribes to and has in fact signed onto the Millennium Development Goals and is fully committed to achieving the goals and targets by the 2015 benchmark date.

Reducing the incidence of poverty by half by 2015 as well as achieving the other goals and targets is central on the development planning agenda.

Despite the ravages the hurricanes and the impacts on the national economy measured by global events, the Government is fully committed to promote the achievement of the country's obligations on the regional and international levels.

The overall strategies must be placed within the framework of the international economy. Globalization and liberalization characterized the international economic order. To quote 
James (1999) "An increasingly globalized capitalist market and an intensified drive for the States to rely on "free competition" characterize the current economic order. If developing countries, like Grenada are unable to improve their capacity to compete in this ever increasing globalization, they face increased poverty, unemployment and underdevelopment".

This means that Grenada must immediately identify the activities for which it has a competitive advantage. These activities should be able to generate high income', stimulate growth and enable the Government to implement its poverty eradication strategies. Globalization presents both challenges and opportunities.

The challenges include: the need to create a highly literate and productive labour force which is efficient and effective; to harness the energy and will of Grenadians to ensure that they build their social capital and commit themselves to the national development plan, and; to improve social conditions and at the same time achieve economic growth.

The opportunities are real, and based on the most recent available data. Grenada is on a path of economic recovery. This economic recovery must be maintained and all efforts must be made to ensure that a large proportion of Grenadians are not marginalized in the process.

\subsection{Medium Term Framework}

Grenada's medium term reform programme entitled "Economic Growth, Poverty Alleviation and Macroeconomic Stability" details a series of objectives and policies the Government intends to pursue during the period 2006-2008. The main elements of the programmes are:

- Promotion of sustained high economic growth by improving the climate for private investment;

- Restoration of fiscal and debt sustainability through fiscal consolidation and reform;

- Reduction in vulnerabilities by safeguarding the soundness of the financial system;

- Reduction of poverty through more effective social development programmes and safety nets.

\section{Sustained High Economic Growth}

The medium term reform programme is expected to sustain economic growth on the order of at least 4 percent per annum. The private sector is expected to play an enhanced role and Government will develop a more proactive policy environment that is conducive to private sector investments. Institutional strengthening of the national private sector development agencies, improving the manner in which land is available for investors and comprehensive reform to improve the tax systems transparency and accountability are on the agenda. The programme also includes consolidation of the public sector modernization programme and activities geared to enhance labour and product market flexibility. 


\section{Fiscal and Debt Sustainability}

The medium term programme will include specific measures to reduce Grenada's public debt stock which is unsustainable at 130 percent of GDP to 60 percent of GDP by 2015. The programme includes fiscal consolidation to allow the fiscal accounts to swing from a primary deficit of 2 percent of GDP in 2005 to a primary surplus of 2.5 percent of GDP in 2008.

\section{Reducing Vulnerabilities}

The medium term programme will includes specific measures to reduce Grenada's vulnerabilities to natural disasters and to safeguard the soundness of the financial sector.

\section{Reducing Poverty}

The medium term programme includes specific measures aimed at reducing poverty. Targeted poverty reduction initiatives will be undertaken. At the same time, a comprehensive poverty reduction strategy and action plan will be elaborated following a detailed poverty assessment survey.

\subsection{Programme Elements}

The programme elements of the medium term macroeconomic framework include the following:

- Strengthening investment promotion;

- Preparation of new investment code;

- Facilitating land transaction through an upgrade of the land registry and establishment of a new executive agency;

- Strengthening customs clearance;

- Implement an export strategy;

- Review of the effectiveness of the labour market;

- Rationalizing price controls;

- Enhancing small business development;

- Improving the structure and efficiency of public finances;

- Introduction of an automatic fuel price mechanism;

- Introduction of a 5 percent national reconstruction levy on wages and salaries to finance the reconstruction effort;

- Strengthening of tax administration;

- Collection of arrears of taxes;

- Revision of property valuations;

- Conducting negotiations with unions to determine a wage path no greater than average annual inflation;

- Strengthening of the PSIP planning and implementation; 
- Undertaking a series of measures to control and lower recurrent expenditures including reduced spending on goods and services and the introduction of an appropriately targeted safety net for the poor, elderly and needy students.

- Targeting of about one-quarter of the underlying medium term fiscal consolidation in the 2006 budget;

- Targeting of a 2006 primary deficit of 7.6 percent of GDP;

- Introducing a comprehensive tax and civil service reform;

- Improving fiscal transparency and reporting;

- Introduction of a system of value added taxes by January 2008;

- Rationalizing of the tax incentives system including moratorium on tax holidays, introduction of a system of tax write-offs for investments and the introduction of a system of accelerated depreciation with loss carry forward provision;

- Removing the existing system of consumption taxes with the introduction of a broad-based VAT with a lower rate and fewer exemption by 2008 ;

- Reforming the import duty regime with the introduction of inter alia import duty exemptions for exporters and selected tourism services;

- Repealing of the Investment Code Incentives and Qualified Entrepreneurs Act by May 2006;

- Lowering of the corporate income tax threshold in a gradual manner to provide incentives for higher private sector investments;

- Improving the efficiency and quality of government services through inter alia, enhancement of the performance appraisal system and commercialization of selected government services;

- Implementing the public sector modernization programme which includes the maintenance of a freeze on public sector positions, the introduction of greater flexibility in empowerment and separation decisions, decompression of the wage scale, introduction of a system of awards for high performances and a rebalance of the civil service mix towards more professional staff as against clerical positions;

- Improving the transparency of public finance and strengthening fiscal monitoring including inter alia, the regular dissemination of information publicly on fiscal and economic situation, strengthening budgetary process and accountability through audit reform and strengthening, and reporting requirements;

- Implementing and consolidating the Government debt exchange offers including infrastructure of dialogue with official creditors for debt relief;

- Strengthening the debt management capacity and transparency;

- Divesting of a select portfolio of Government assets using the proceeds for debt retirement and to finance approved capital expenditures;

- Undertaking independent professional on site inspection of the banking system by June 2006;

- Enacting of the Grenada Authority for the Regulation of Financial Institutions and strengthening the administrative machinery for financial management;

- Strengthening national capacity to deal with natural disasters including the enforcement of the building code, the strengthening of the regulation of the insurance sector and participate in the "World Bank's Catastrophic Risk Insurance Project" which is designed to pool insurance risks across countries; 
- Undertaking the implementation of the various recommendations in the post hurricane reconstruction and development programme including the housing development, agriculture rehabilitation and development, the Core Welfare Indicator Questionnaire Survey, and the infrastructure development programme.

\subsection{Elements of National Poverty Eradication Strategy}

Grenada's Poverty Eradication Strategy focuses on the following priority elements:

- Economic recovery for sustained robust economic growth;

- Agriculture rehabilitation and development

- Housing development;

- Reduced unemployment;

- Improved access to social infrastructure;

- Human resources development;

- Modernization of estate service machinery;

- Improved environmental management;

- Social safety net programmes.

These priority areas show some significant overlaps, for example sustained robust economic growth necessarily involves improvement in the human capital stock; reduced unemployment; modernize state machinery and improved social infrastructure.

Sustained progress in addressing the issue will be possible only with the meaningful involvement of all stakeholders. The drive to eradicate poverty should be viewed in a holistic manner. The priority areas, and all areas for that matter, must be dealt with simultaneously. Resources and capacity limitations may mean prioritization of activities under the broad categories but a national, integrated and holistic picture of the poverty eradication programme has to be prevalent. Under the programme, adequate resources should become available for the effective management of the poverty eradication programme.

Economic growth and development is the overarching objective of Grenada's poverty eradication strategy, but it must be implemented with access to social services in particular education, health, water, housing and employment. The strategy therefore will entail detailed activities in those specific areas and the priority sectors of agriculture, housing, health, education and tourism.

Starting in early 2006, a full-fledged Poverty Eradication Strategy Paper will be elaborated, using this interim document as its starting base. The strategy will be established following an extensive consultation process that will involve all major stakeholder groups throughout the country, including in particular civil society organizations and the private sector. It will aim at further sharpening the focus and coherence of the poverty reduction initiatives, ensuring that scarce resources are directed to the neediest in society in an effective and efficient manner. In addition, it will forge close links to the poverty reduction objectives 
and social development programmes while ensuring consistency with overall macroeconomic and fiscal objectives, and achieving the Millennium Development Goals (MDG).

More specifically, the Poverty Reduction Strategy Paper will seek to achieve the following:

- Adopt a forward-looking and strategic approach, clearly defining the goals for poverty reduction and spelling out steps needed to achieve Grenada's poverty reduction objectives, including the Millennium Development Goals (MDGs).

- Evaluate the effectiveness of existing poverty alleviation programmes, with a view to making better use of empirical evidence to assess programme effectiveness. In addition, it will define which institution or agency is responsible for which objectives; the size, financing and duration of programmes; and the modes and timeframe of implementation.

- Prioritize programmes and policies according to their desirability and social effectiveness. Detailed costing - separating investment outlays from expected recurrent costs for future maintenance and operation - will be made part of the benefits analysis, to facilitate the evaluation of consistency with the fiscal objectives of the macro-economic framework, the PSIP, and available domestic and external resources.

\subsection{MONITORING INDICATORS, RISK AND COSTING}

\subsection{Monitoring Indicators}

The Government is committed to create a poverty coordination unit and build up monitoring and reporting capability within the Ministry of Finance and Planning. The unit will be charged with the design of a database, collection and analysis of information on poverty, coordination of all aspects of the poverty eradication programme, and collaboration with all relevant stakeholders.

Thus, the unit will provide the required leadership and championing of the national fight against poverty. The unit will be responsible for the management of the Poverty Eradication Programme. It will be guided by a broad-based National Poverty Eradication Monitoring Committee.

A set of key indicators for the monitoring of the national poverty condition will be identified and discussed in the framework of the forthcoming national consultations. The indicators will be grouped along eight major categories, namely: economic, health, education, labour and employment, population, poverty and well-being, housing, and the environment.

A basic data set of indicators will be regularly monitored at the national level and updated at least annually in the context of the review of the national poverty eradication strategy. 
Based on consultations held with civil society, it was agreed that due to capacity limitations, simple, early and easily monitorable and verifiable indicators should be tailored specifically to the community groups. These community level indicators will then complement information at the national level. Civil society organizations will be in charge of determining and managing these indicators at the community level.

The monitoring strategy will require the strengthening of various data collection agencies that still present significant capacity limitations.

\subsection{Risks}

The poverty eradication programme calls for the full and effective participation by all citizens in its implementation. The role of NGOs and community-based organizations which have a demonstrated capacity to promote poverty eradication initiatives will be of particular importance.

The Government intends to establish the appropriate regulatory and institutional framework and provide the necessary resources, which should be appropriately targeted.

A key challenge for the success of the strategy will be to ensure sustainable economic growth in the framework of stable institutions, which will have to rely on equitable, accountable, and fully transparent political systems.

Grenada is prone to two types of exogenous shocks: As noted earlier, high vulnerability to a range of natural disasters which can at any time seriously erodes the gains achieved under the Poverty Eradication Strategy. Also, unforeseen developments in the international economic environment could have significant negative impacts on the small and open Grenadian economy.

The Government is determined to address these risks by focussing its attention on investing in a long-term effort to build the necessary technical capacity on the national level, with government working along with civil society and the regional and international partners to strengthen its poverty eradication agenda.

\subsection{Costing}

Providing sufficient financing the implementation of the Poverty Eradication Strategy is a major concern of the Government and civil society. In fact, a lack of appropriate means represents a serious risk factor for the successful implementation of the programme. The Government is committed to explore, in the framework of its macro-economic programme, all financing options available. These include ordinary resources mobilized in the national budget - recurrent and capital revenue, savings from quasi-government bodies and privatization operations - and contributions from regional and international donors and financial institutions. 
The Government's macro-economic programme presents evidence of a significant need to secure new and additional resources to ensure the integral implementation of the poverty eradication programme. It intends to mobilize resources for its fight against poverty mainly from concessional sources, taking into account the constraints on its limited debt-servicing capacity.

The envisaged expenditure programme on the national level is consistent with the overall macro-economic objectives outlined earlier in this document. Significant gaps between the Medium Term Public Sector Investment Programme (PSIP), limited technical absorptive capacity to effectively manage expenditure programmes, and the desired levels of expenditure under National Poverty Eradication Programme to reach its objectives will be addressed with particular care with a view to secure adequate new and additional resources and strengthen the link between budgeting and effective programme execution. 


\section{References}

\section{Sector Studies:}

Charles Leon D. 2002 "Increasing the Positive Impact on Poverty Eradication in Grenada". Ministry of Finance.

Frederick Crispin 2002 Poverty Eradication Through Education”. Ministry of Finance.

John Desmond 2002 "Poverty in the Agricultural Sector in Grenada". Ministry of Finance.

Tarlie Francis 2002 “Audit of Social Development initiatives, Social Development Programmes and Poverty Reduction Projects". Ministry of Finance.

Henry-Lee Aldrie et al 2002. " "Analysis of Public Expenditure on Social Services and Prospects for pro-poor Budgeting in Grenada”. Ministry of Finance.

\section{Other References:}

Government of Grenada 2006 "2006 Estimates of Revenue and Expenditure”

Government of Grenada 2005 "Memorandum of Economic Policies"

Government of Grenada 2005 Aide Memoire of IMF Mission to Grenada

Government of Grenada 2005 “Grenada Core Welfare Indicators Questionnaire (CWIQ) Survey Basic Report"

Government of Grenada 2005 "Grenada: Macro-Socio-Economic Assessment of the Damages Caused by Hurricane Emily"

Government of Grenada 2004 "Grenada: Macro-Socio-Economic Assessment of the Damages Caused by Hurricane Ivan"

Government of Grenada. 2000 “Grenada Medium-term Economic Strategy Paper”, 2000 - 2002

Government of Grenada. 2003 Grenada Medium-term Economic Strategy Paper”, 2003 - 2005

Government of Grenada. 2000 "International Monetary Fund Report". Ministry of Finance

Government of Grenada. 1998. “Draft Labour Force Survey”. Ministry of Finance.

Government of Grenada. 1999. "Poverty Assessment Report”. Ministry of Finance. 
Government of Grenada. 2004. "Status of the Economy". Ministry of Finance

Government of Grenada. Various Years. "Estimates of Revenue and Expenditure”. Ministry of Finance.

Government of Grenada. Various Years. “Budget Speech Documents”. Ministry of Finance 
Annex 1

\subsection{POVERTY ERADICATION MATRIX AND RELEVANT DATA PROFILE}

Poverty Eradication Matrix

\begin{tabular}{|c|c|c|c|}
\hline $\begin{array}{l}\text { Policy } \\
\text { Area/Objectives }\end{array}$ & $\begin{array}{l}\text { Strategies and } \\
\text { Measures }\end{array}$ & Targets & Broad Indicators \\
\hline $\begin{array}{l}\text { I. Education } \\
\text { Improve the quality of } \\
\text { primary, secondary and } \\
\text { tertiary education }\end{array}$ & $\begin{array}{l}\text { Modernize and upgrade all } \\
\text { educational facilities } \\
\text { Increase use of computers in } \\
\text { schools } \\
\text { Establish functioning learning } \\
\text { resource centres in primary } \\
\text { and secondary schools } \\
\text { Improve teacher training and } \\
\text { development instruments } \\
\text { relating to } \\
\text { professional teaching standards } \\
\text { Review conditions of teaching } \\
\text { service } \\
\text { Develop an improved teacher } \\
\text { supervision system } \\
\text { Develop a } \\
\text { competency based approach to } \\
\text { the evaluation of learning at } \\
\text { primary and secondary levels } \\
\text { Strengthen continuous } \\
\text { assessment at primary and } \\
\text { secondary level. Train teachers } \\
\text { in diversified testing } \\
\text { modalities }\end{array}$ & $\begin{array}{l}\text { Rehabilitate all primary and } \\
\text { pre-primary schools by } 2007 \\
\text { At least } 10 \text { computers in each } \\
\text { primary school by } 2007 \\
1 \text { Resource centre per school } \\
\text { established by } 2007 \\
\text { Increase number of trained } \\
\text { /graduate teachers to } 75 \% \text { by } \\
2007 \\
\text { Instruments and Code of ethics } \\
\text { in place by } 2005 \\
\text { Condition of service reviewed } \\
\text { and implemented } \\
\text { System reviewed and in place } \\
\text { by } 2006 \text {. } \\
200 \text { Supervisors and inspectors } \\
\text { trained by } 2006 \\
\text { Minimum national standards of } \\
\text { achievement in math, english } \\
\text { and science developed and } \\
\text { implemented by } 2008 \\
\text { All teachers trained by } 2007 \text {. } \\
\text { System implemented by } 2008\end{array}$ & $\begin{array}{l}\text { \# of primary and pre-primary } \\
\text { schools upgraded } \\
\text { \# of computers installed } \\
\text { \# of schools receiving computers } \\
\text { \# of resource centres established } \\
\text { \# and \% of trained and graduate } \\
\text { teachers by level of education and } \\
\text { sex } \\
\text { Code of ethics adopted and } \\
\text { implemented } \\
\text { Improved teacher morale } \\
\text { \# of supervisors and inspectors } \\
\text { trained by level of education and } \\
\text { sex } \\
\text { level of teacher responsiveness to } \\
\text { new system } \\
\text { Student performance on national } \\
\text { competency standards in selected } \\
\text { areas by sex } \\
\text { \# of teachers trained in continuous } \\
\text { assessment methods by level of } \\
\text { education and sex }\end{array}$ \\
\hline
\end{tabular}




\begin{tabular}{|c|c|c|c|}
\hline Issues/Objectives & Strategies and Measures & Targets & Broad Indicators \\
\hline $\begin{array}{l}\text { Education (cont'd) } \\
\text { Improve } \\
\text { effectiveness of education } \\
\text { management }\end{array}$ & $\begin{array}{l}\text { Enact and enforce revised } \\
\text { education act } \\
\text { Establish fully functioning school } \\
\text { boards }\end{array}$ & & \\
\hline $\begin{array}{l}\text { Achieve universal access } \\
\text { to education by } 2010\end{array}$ & $\begin{array}{l}\text { Achieve universal access to } \\
\text { primary education by } 2003 \\
\text { Increase access to secondary } \\
\text { education } \\
\text { Expand access to tertiary } \\
\text { education. } \\
\text { Strengthen monitoring of truancy } \\
\text { Establish/upgrade TVET centres }\end{array}$ & $\begin{array}{l}100 \% \text { net primary enrolment ratio } \\
\text { (NER) by } 2003 \\
5 \text { years secondary education for all } \\
\text { eligible, by } 2008 \\
\text { Achieve minimum of } 15 \% \text { of post } \\
\text { secondary age cohort enrolled by } \\
2005 ; 30 \% \text { by } 2010 \\
\text { Reduce truancy to } 8 \% \text { by } 2005 \text { and } \\
2 \% \text { by } 2008 \\
\text { Double existing capacity by } 2008\end{array}$ & $\begin{array}{l}\text { - Primary NER by sex and age } \\
\text { secondary NER by sex and age } \\
\text {-secondary completion rate by } \\
\text { sex } \\
\text {-NER by sex and age } \\
\text {-\# of graduates by sex } \\
\text { truancy rate by age and sex } \\
\text {-\# of centres established. }\end{array}$ \\
\hline . & $\begin{array}{l}\text { Establish fully functioning Parent } \\
\text { Teacher Associations } \\
\text { Engage the media in promoting } \\
\text { education } \\
\text { Improve working relationship } \\
\text { with national, regional and } \\
\text { international organisations. }\end{array}$ & $\begin{array}{l}\text { All schools with functioning PTA } \\
\text { by } 2006 \text {. National PTA BY } 2008 \\
\text { Develop and implement a } \\
\text { comprehensive media programme } \\
\text { by } 2006 \\
\text { Attend various regional, } \\
\text { international meeting, } \\
\text { Mobilise private sector to assist in } \\
\text { selected areas of education } \\
\text { development }\end{array}$ & $\begin{array}{l}\text { \# of schools with functioning } \\
\text { PTA } \\
\text { \# of programmes broadcast } \\
\text { \# of media houses participating } \\
\text { in programme. } \\
\text { public response to programmes } \\
\text { \# of meetings attended } \\
\text { rate of increase in external } \\
\text { funding grant }\end{array}$ \\
\hline
\end{tabular}




\begin{tabular}{|c|c|c|c|}
\hline Issue/Objectives & Strategies and Measures & Targets & Broad Indicators \\
\hline $\begin{array}{l}\text { Education (cont'd) } \\
\text { Provide learners with relevant } \\
\text { knowledge, attitudes and skills for } \\
\text { daily life and the job market }\end{array}$ & $\begin{array}{l}\text { Total revision of education curricula } \\
\text { Establish a comprehensive Tec Voc } \\
\text { programme that responds to HRD needs } \\
\text { Develop secondary and tertiary level } \\
\text { programmes that responds to labour } \\
\text { market requirements } \\
\text { Develop Labour Market Information } \\
\text { System }\end{array}$ & $\begin{array}{l}\text { All curricula fully revise by } 2007 \\
\text { Programme established by } 2008 \\
\text {-Private sector consultations } \\
\text { completed by } 2006 \\
\text {-Secondary and Associate degree } \\
\text { programmes developed by } 2009 \\
\text { LMIS establish and running by } \\
2006\end{array}$ & $\begin{array}{l}\text { \# of curricula revised } \\
\text { Revised programme } \\
\text { prepared } \\
\text { \# of consultations held } \\
\text {-\# of participants in } \\
\text { consultations } \\
\text { - \# of programmes } \\
\text { developed } \\
\\
\text { \# of persons using LMIS } \\
\text {-register of graduated } \\
\text { established. }\end{array}$ \\
\hline $\begin{array}{l}\text { Increase government spending on } \\
\text { education }\end{array}$ & $\begin{array}{l}\text { Present well development education } \\
\text { projects for budgetary support } \\
\text { Upgrade and strengthen teacher training } \\
\text { institutions } \\
\text { Institutional strengthening of Ministry of } \\
\text { Education } \\
\text { Establish focus on early childhood } \\
\text { education } \\
\text { Private sector community involvement in } \\
\text { education reform } \\
\text { Implementation of education reform } \\
\text { programme } \\
\text { Upgrading of TAMCC }\end{array}$ & $\begin{array}{l}\text { Education budget increased by } \\
10 \% \text { per annum over } 2000 \text { levels }\end{array}$ & $\begin{array}{l}\text { Education as \% of total } \\
\text { budget. } \\
\text { Increase in budgetary } \\
\text { allocations to education }\end{array}$ \\
\hline
\end{tabular}




\begin{tabular}{|c|c|c|c|}
\hline Issue/Objectives & Strategies and Measures & Targets & Broad Indicators \\
\hline $\begin{array}{l}\text { II. Health } \\
\text { Reduce the incidence of malnutrition, } \\
\text { low birth weight, infant mortality and } \\
\text { anemia in children. }\end{array}$ & $\begin{array}{l}\text { Encourage breast-feeding. } \\
\text { Re-introduce / } \\
\text { Strengthen school feeding programme. } \\
\text { Increase attendance at prenatal clinics. } \\
\text { Improve attendance of the poor to well baby } \\
\text { clinics. } \\
\text { Continue health education programmes }\end{array}$ & $\begin{array}{l}\text { Increase } \% \text { of babies solely } \\
\text { breast fed for first three } \\
\text { months from } 34 \% \text { in } 2000 \text { to } \\
75 \% \text { by } 2006 \text {. } \\
\text { School feeding programme } \\
\text { in all primary schools in } \\
\text { rural areas by } 2006 \text {. } \\
95 \% \text { of pregnant women } \\
\text { attend prenatal clinic by } \\
2006 \text { from } 80 \% \text { in } 2000 \\
\text { Reduce infant mortality from } \\
12.5 / 1000 \text { in } 2000 \text { to } 9 / 1000 \\
\text { by } 2006\end{array}$ & $\begin{array}{l}\text { \% of babies solely } \\
\text { breast-fed. } \\
\text { Under five malnutrition } \\
\text { rate }(\%) \text {. } \\
\text { \% babies with low birth } \\
\text { weight. } \\
\text { Prevalence of anemia } \\
\text { among one year olds. } \\
\% \text { of women attending } \\
\text { prenatal clinic. } \\
\text { Infant mortality rate } \\
\text { \% of health budget for } \\
\text { programmes }\end{array}$ \\
\hline $\begin{array}{l}\text { Reduce the incidence of communicable } \\
\text { diseases }\end{array}$ & $\begin{array}{l}\text { Expand immunisation among all 0-1year } \\
\text { olds. } \\
\text { Expand immunisation of all school age } \\
\text { children. Against the six childhood diseases } \\
\text { and rubella. } \\
\text { Increase immunisation of antenatal mothers } \\
\text { at or before first visit. } \\
\text { Intensify and expand the vector control. } \\
\text { programme, mainly through community } \\
\text { awareness. }\end{array}$ & $\begin{array}{l}100 \% \text { immunisation by } 2006 \\
\text { from } 97 \% \text { in } 2000 \text {. } \\
70 \% \text { of all school age } \\
\text { children immunised by } 2006 \\
75 \% \text { mothers immunised } \\
\text { against tetanus by } 2006\end{array}$ & $\begin{array}{l}\text { Under one year } \\
\text { immunisation rate } \\
\text { Child immunisation rate } \\
\text { Antenatal mothers } \\
\text { immunised rate (\%) } \\
\text { Morbidity rates } \\
\text { \% expenditure on } \\
\text { immunisation and } \\
\text { preventative health. }\end{array}$ \\
\hline
\end{tabular}




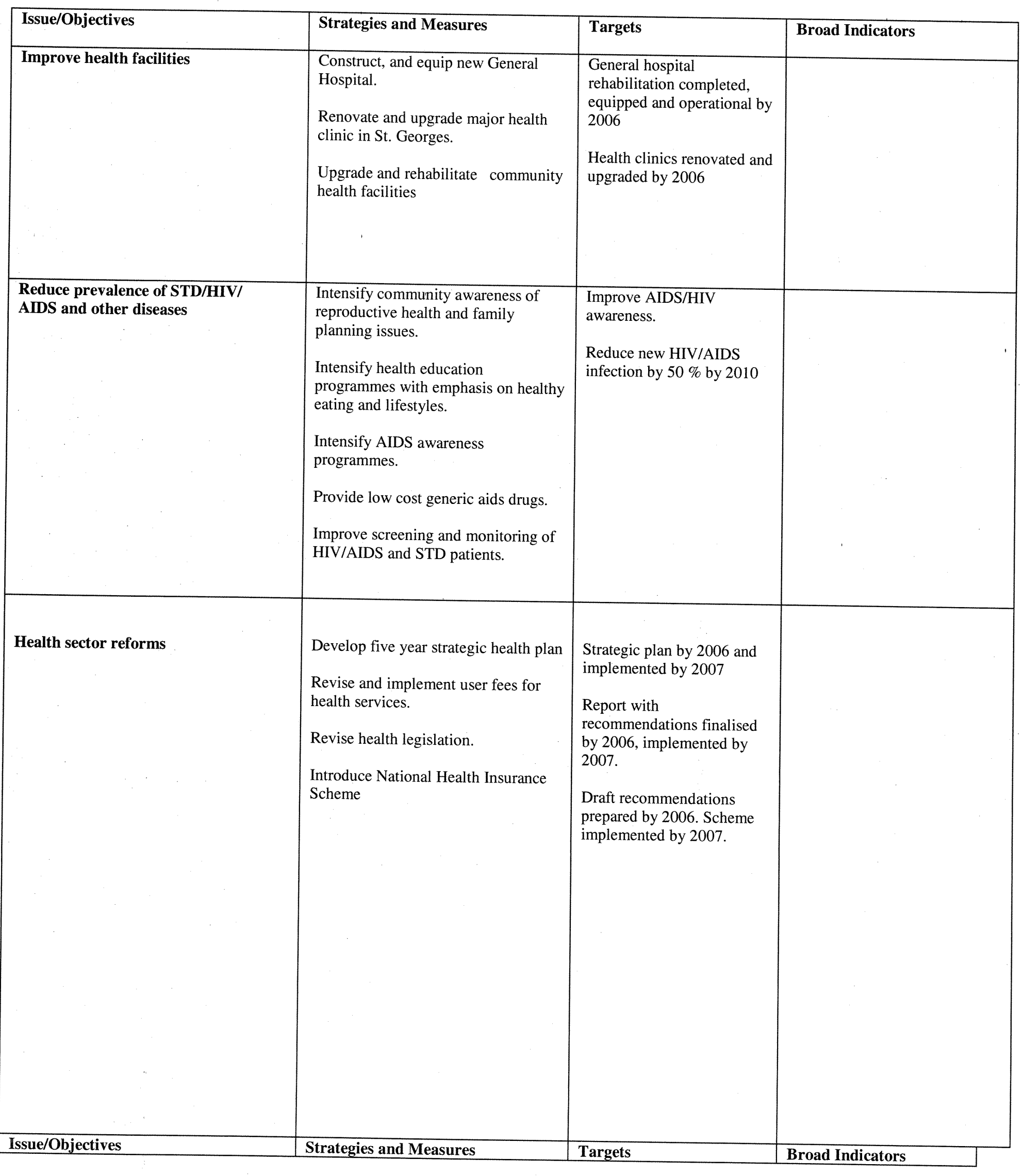




\begin{tabular}{|c|c|c|c|}
\hline & & & \\
\hline 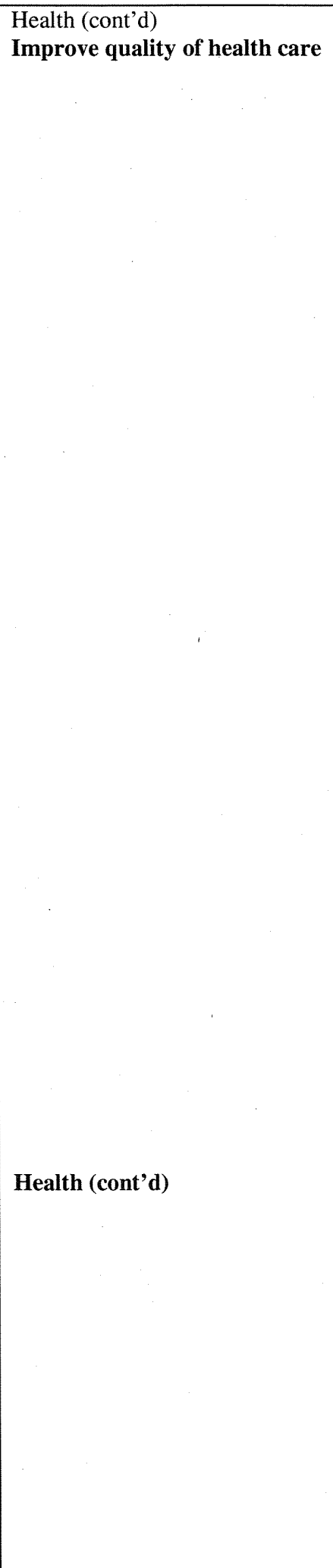 & 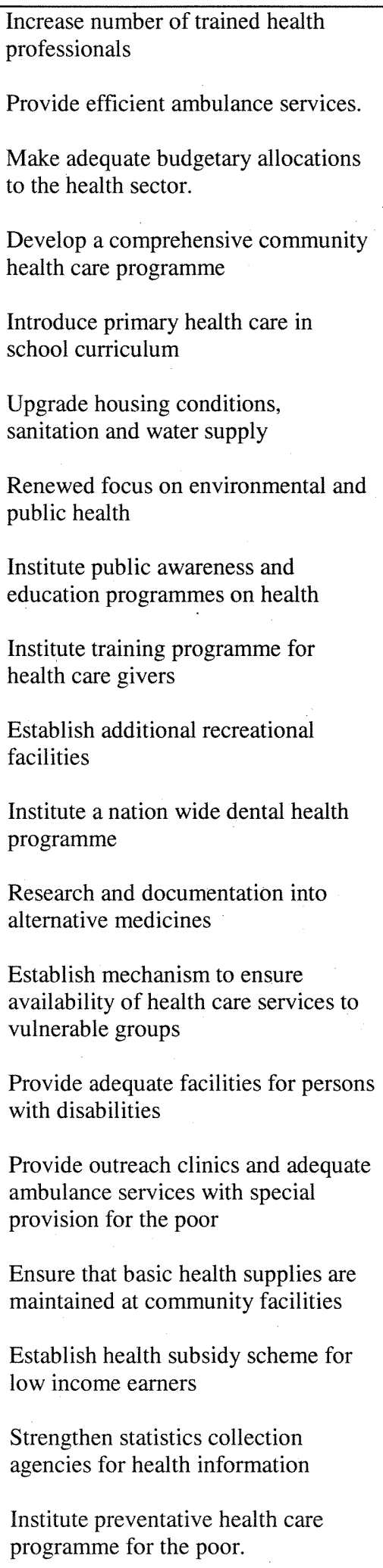 & $\begin{array}{l}\text { Increase no of specialist } \\
\text { doctors by } 10 \% \text { by } 2006 \text {. } \\
\text { Increase specialised training } \\
\text { for nurses and other health } \\
\text { care professionals by } 10 \% \\
\text { by } 2006 \\
\text { One ambulance per major } \\
\text { health centre by } 2006 \text {. }\end{array}$ & $\begin{array}{l}\text { Population-doctor ratio } \\
\% \text { of specialists } \\
\text { \# nurses receiving } \\
\text { specialised training. } \\
\text { \# of ambulances } \\
\text { available } \\
\text { Total Health budget as \% } \\
\text { of national budget }\end{array}$ \\
\hline
\end{tabular}




\begin{tabular}{|c|c|c|c|}
\hline Issue/Objectives & Strategies and Measures & Targets & Broad Indicators \\
\hline $\begin{array}{l}\text { 2. Enhance Fiscal Management } \\
\text { 3.Improve Debt Management } \\
\text { 4.Rationalise Trade Policy } \\
\text { 5.Improve efficiency of Public Sector } \\
\text { 6. Promote Private Sector Development } \\
\text { 7.Expand employment opportunities for } \\
\text { all }\end{array}$ & $\begin{array}{l}\text { Increase the rate of gross capital } \\
\text { formation and national savings. } \\
\text { Improve management and efficiency } \\
\text { of Public Sector Investment } \\
\text { Programme } \\
\text { Rationalise government expenditure. } \\
\text { Increase government revenues. } \\
\text { Improve equity and distributive } \\
\text { efficiency of social expenditure. } \\
\text { Reduce overall debt burden. } \\
\text { Improve financial relations with } \\
\text { external /local creditors. } \\
\text { Support employment generation } \\
\text { initiatives through appropriate fiscal } \\
\text { incentives. } \\
\text { liability } \\
\text { Implemarketing } \\
\text { training programme. } \\
\text { Assist the private sector in responding } \\
\text { to globalisation } \\
\text { Ensure trade regime compatible with } \\
\text { regional and international agreements. } \\
\text { Assist private sector to achieve } \\
\text { economies of scale. } \\
\text { sectionte special consideration for } \\
\text { small states } \\
\text { Conduct legislative review of public } \\
\text { sector }\end{array}$ & $\begin{array}{l}\text { Improve current account } \\
\text { balance. } \\
\text { Increase current revenue } \\
\text { Reduce new debt by } \\
25 \% / y e a r \text { over } 2000 \text { levels } \\
\text { Increase debt payments } \\
\text { Review trade policy by } 2006 \\
\text { Conduct legislative reviews } \\
\text { by } 2008 \\
\text { Implement new tax } \\
\text { legislation by } 2006 \\
\text { Revised public sector } \\
\text { regulations in place by } 2006\end{array}$ & $\begin{array}{l}\text { Fiscal balance } \\
\text { Current account balance } \\
\text { Current revenue \% of } \\
\text { GDP)) } \\
\text { Current expenditure }(\% \text { of } \\
\text { GDP) } \\
\text { Capital expenditure (\% of } \\
\text { GDP) } \\
\text { Tax/GDP ratio } \\
\text { Tax effort } \\
\text { Debt stock } \\
\text { Debt service ratio }\end{array}$ \\
\hline
\end{tabular}




\begin{tabular}{|c|c|c|c|}
\hline $\begin{array}{l}\text { 8. Implement Post Hurricane } \\
\text { Economic Adjustment Programme }\end{array}$ & 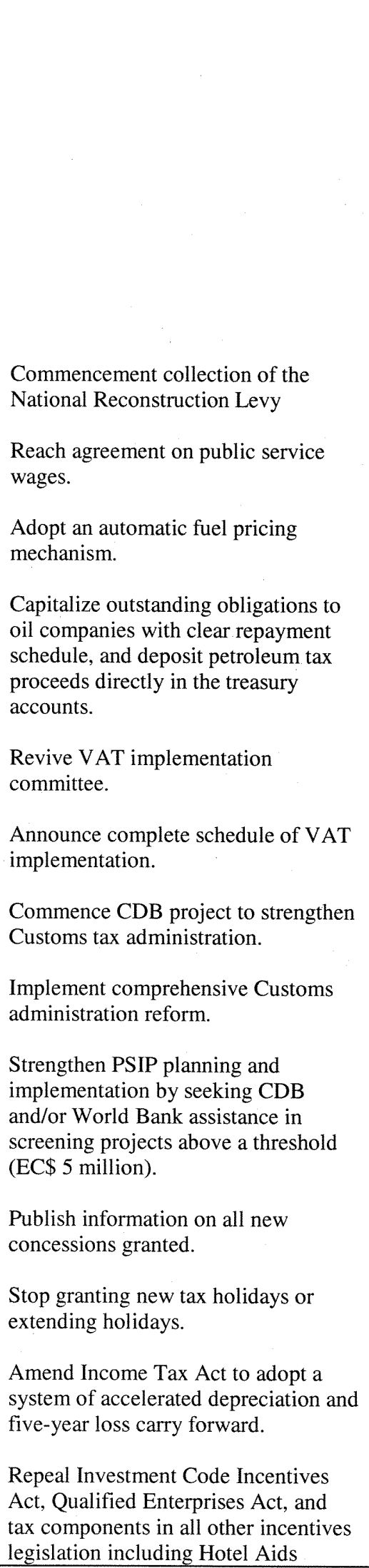 & $\begin{array}{l}\text { At least XCD } 8 \text { million } \\
\text { dollars collected annually. } \\
\text { Agreement for } 2006 \text { - } 2008 \\
\text { reached by March } 2006 . \\
\text { Mechanism implemented by } \\
\text { June } 2006 . \\
\text { Obligations capitalize by } \\
\text { February } 2006 \text {. } \\
\qquad \\
\text { Committee established by } \\
\text { January } 2006 \text {. } \\
\text { Schedule completed by June } \\
2006 . \\
\text { Project commenced by April } \\
2006 . \\
\text { Income Tax Act amended } \\
\text { by May } 2006 . \\
\text { Acts repealed by May } 2006 . \\
\text { Reform implemented by } \\
\text { August } 2006 \text {. } \\
\text { PsiP strengthened by June } \\
2006 . \\
\text { Moratorium established by } \\
\end{array}$ & $\begin{array}{l}\text { \# of departments } \\
\text { commercialised } \\
\text { Private sector role in the } \\
\text { economy improved. } \\
\text { Unemployment rate. } \\
\text { Number of new jobs } \\
\text { created. } \\
\text { Amounts collected. } \\
\text { Agreement document. } \\
\text { Mechanism in place. } \\
\text { Amounts collected. }\end{array}$ \\
\hline
\end{tabular}




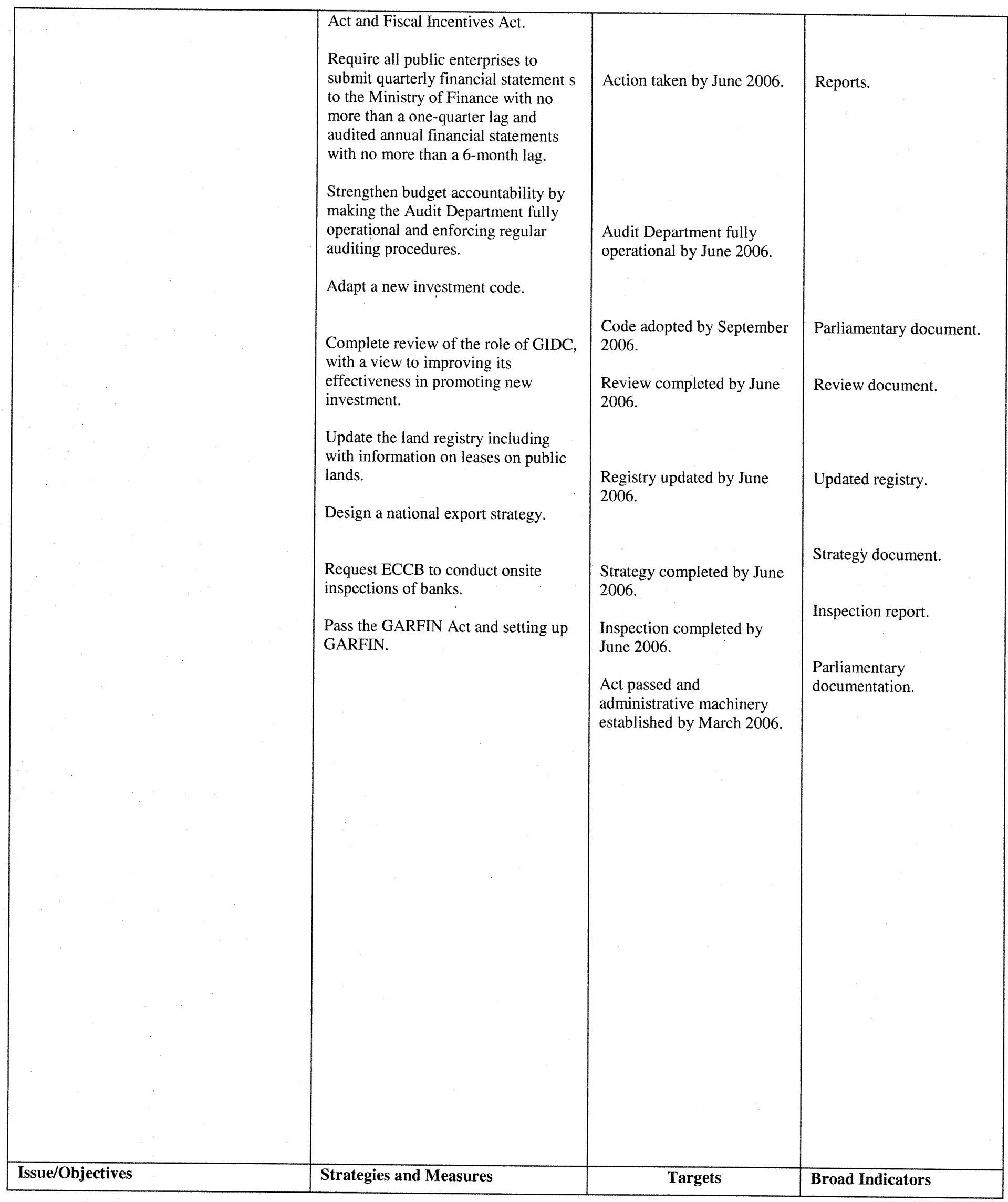




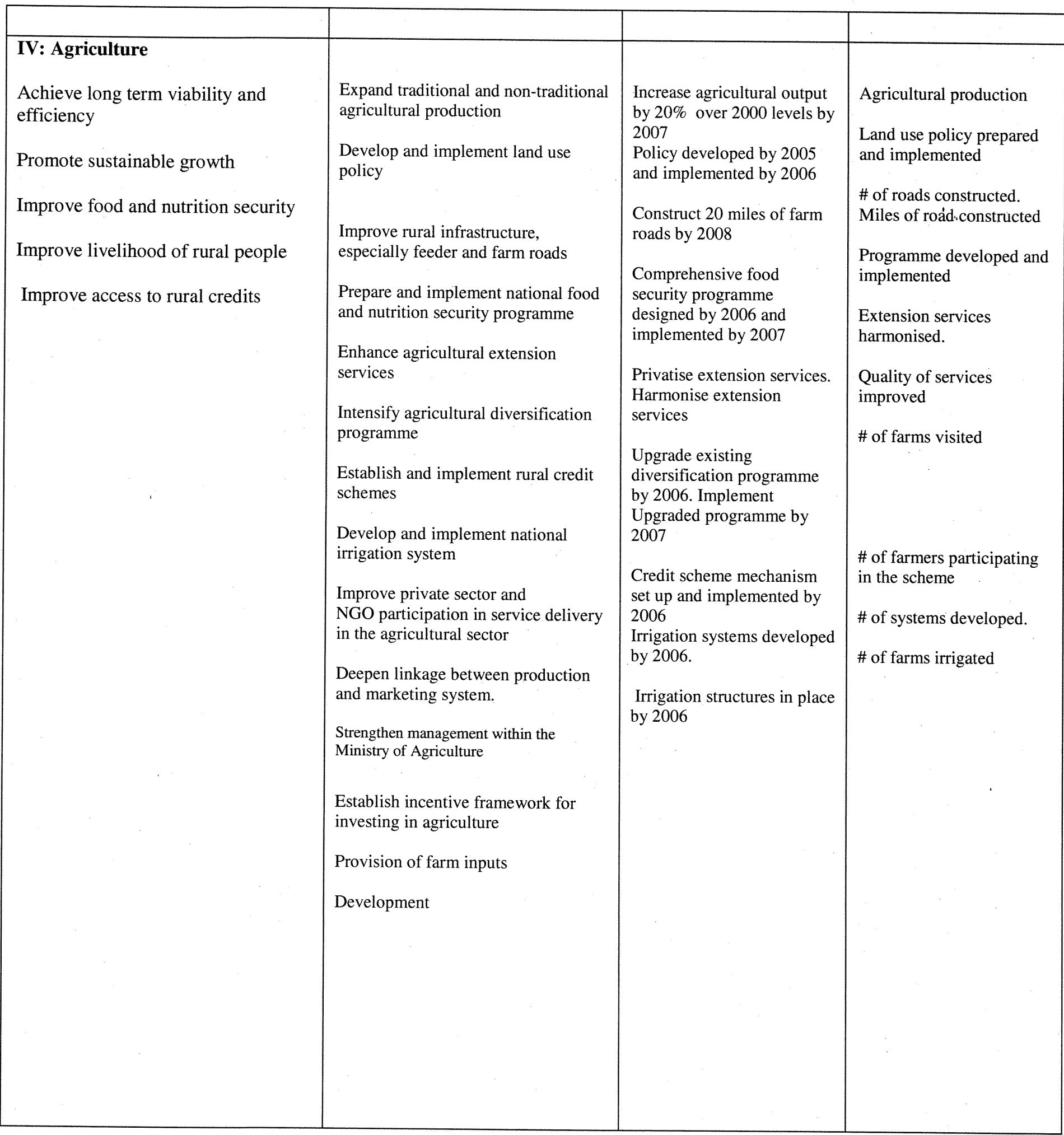




\begin{tabular}{|c|c|c|c|}
\hline Issue/Objectives & Strategies and Measures & Targets & Broad Indicators \\
\hline Agriculture (Cont'd) & $\begin{array}{l}\text { Strengthen management } \\
\text { within the Ministry of } \\
\text { Agriculture } \\
\text { Establish incentive } \\
\text { framework for investing in } \\
\text { Agriculture } \\
\text { Provision of farm inputs } \\
\text { Development of human } \\
\text { resource capacity } \\
\text { Develop sustainable agro } \\
\text { industries } \\
\text { Examine and develop } \\
\text { linkages with the Tourism } \\
\text { sector } \\
\text { Modernization scheme for } \\
\text { agriculture } \\
\text { Institutional strengthening to } \\
\text { provide safety nets for } \\
\text { farmers } \\
\text { Establish farmer retiring } \\
\text { programmes }\end{array}$ & & . \\
\hline
\end{tabular}




\begin{tabular}{|c|c|c|c|}
\hline Policy Area & $\begin{array}{l}\text { Strategies and } \\
\text { Measures }\end{array}$ & Targets & Broad Indicators \\
\hline $\begin{array}{l}\text { V. Tourism } \\
\text { Promote sustainable growth and } \\
\text { development of the Tourism } \\
\text { Sector. } \\
\text { Intensify human resource } \\
\text { development and training } \\
\text { Improve product development }\end{array}$ & $\begin{array}{l}\text { Implement three year } \\
\text { marketing plan } \\
\text { Implement small hotel } \\
\text { special assistance project } \\
\text { Continuous training of } \\
\text { players in the hotel } \\
\text { sector } \\
\text { Increase number of } \\
\text { flights, including } \\
\text { charters } \\
\\
\text { Enhance cruise ship } \\
\text { tourism product } \\
\text { Implement historical } \\
\text { and cultural sites } \\
\text { development } \\
\text { programmes } \\
\text { Commercialise selected } \\
\text { tourism attraction sites }\end{array}$ & $\begin{array}{l}\text { Marketing plan fully } \\
\text { implemented by } 2005 \\
\text { Assist } 50 \% \text { of small hotels by } \\
2007 \\
500 \text { players in the tourism } \\
\text { sector trained by } 2007 \\
\text { Flights increase by } 20 \% \text { by } \\
2007 \\
\text { Three new airlines flying into } \\
\text { Grenada by } 2007 \\
\text { Forts restoration project } \\
\text { implemented by } 2007 \text {. }\end{array}$ & $\begin{array}{l}\text { Hotel occupancy rate } \\
\text { Visitor arrivals } \\
\text { \# of small hotels assisted } \\
\text { \# of persons trained by sub-sectors } \\
\text { \# of airlines flying to Grenada } \\
\text { Number of visitors to fort. }\end{array}$ \\
\hline
\end{tabular}




\section{Annex 2}

\subsection{Consultation Record}

1. Individual / sector level

2. Stakeholder consultations
Sectors included agriculture, education, social services, health, social audit, indicators and general considerations.

Several individuals were targeted for personal interviews.

Several groups of stakeholders were selected

These include the following:

Cabinet

Board of Permanent Secretary

Sustainable Development Council

Multipartite

National Teachers Association

Conference of Churches

Church for Social Action

Inter Agency Group of Development

Organizations

Service Organization

T. A. Marryshow Community College

Parish based Development Organizations

National Youth Council

Elderly Organizations

Community Boards

Farmers Organizations

Fishermen Organizations

Chamber of Commerce

Grenada Industrial Development Corporation

Small Enterprise Development Unit

Trade Unions

Police and Security Services

Bar Association

Magistracy

National Insurance Scheme

Grenada International Financial Services

Authority

Media

Financial Institutions

Banks 


\section{Private Companies}

3. Community level consultations

4. Parish level consultations

5. National consultations
Nineteen (19) poor communities based on the Poverty Assessment Report were selected for focus community level consultations.

Six (6) consultations were held one (1) in each Parish and a seventh consultation was held on the island of Carriacou. Residents of Petit Martinique were transported to Carriacou to attend the consultation.

Two (2) national consultations including representatives from all major stakeholders were invited to attend. Over 75 persons attended each of the consultation, which was covered by the media. 